\title{
Joint of Modeling Techniques and Life Cycle Assessment for Prediction of Yield, Economic Profit, and Global Warming Potential for Wheat Farms
}

Hassan Ghasemi-Mobtaker

University of Tehran

Ali Kaab ( $\nabla$ kaab.ali@ut.ac.ir)

Tehran University: University of Tehran https://orcid.org/0000-0002-6334-5255

Shahin Rafiee

Tehran University: University of Tehran

\section{Research Article}

Keywords: Energy, Economic analysis, Global warming, Modeling, Wheat

Posted Date: March 15th, 2021

DOI: https://doi.org/10.21203/rs.3.rs-174760/v1

License: (c) (i) This work is licensed under a Creative Commons Attribution 4.0 International License.

Read Full License 
Joint of modeling techniques and life cycle assessment for prediction of yield, economic profit, and global warming potential for wheat farms

Authors

6 Hassan Ghasemi-Mobtaker ${ }^{1, *}$, Ali Kaab ${ }^{1, * *}$, Shahin Rafiee ${ }^{1}$

7

8

10 1-Department of Agricultural Machinery Engineering, Faculty of Agricultural Engineering and Technology, University of Tehran, Karaj, Iran

12

13

Hassan Ghasemi-Mobtaker (mobtaker@ut.ac.ir)

Ali Kaab (kaab.ali@ut.ac.ir)

17

\section{Complete Postal Address:}

19 Department of Agricultural Machinery Engineering, Faculty of Agricultural Engineering and Technology, University of Tehran, Karaj, Iran

Fax: +98 2612808138 
Joint of modeling techniques and life cycle assessment for prediction of yield, economic

\section{profit, and global warming potential for wheat farms}

\section{Abstract}

27 Forecasting crop yield and its environmental effects can help increase agricultural energy 28 efficiency and reduce environmental impacts. This study provides mathematical, adaptive network-based fuzzy inference system (ANFIS) and neural networks (ANNs) techniques for forecast yield, economic profit, and global warming of wheat production. For this purpose, 75 wheat farms located in the central area of Hamadan province were selected randomly and data were gathered through oral interview. Then, computed the input and output energy, life cycle assessment (LCA) was utilized to specify the environmental effects of wheat cultivation. The calculations displayed that the averages of inputs and outputs energy were about $43055 \mathrm{MJ} \mathrm{ha}^{-1}$ and $117407 \mathrm{MJ} \mathrm{ha}^{-1}$, respectively. The LCA results demonstrated that wheat cultivation cause to the emissions of $624.29 \mathrm{~kg} \mathrm{CO}_{2}$ eq. $\operatorname{ton}^{-1}$. ANN structures for predicting yield, economic profit and global warming in wheat production with two hidden layers were the best topologies. ANFIS model results indicated that in the 3-level ANFIS model, the highest $\mathrm{R}^{2}$ is found for net return (0.962). The results comparison showed that ANN and ANFIS models outperform linear models to predict yield, economic profit, and global warming of wheat production.

Keywords: Energy, Economic analysis, Global warming, Modeling, Wheat

\section{Introduction}

44 Today, one of the essential topics of producers and governments is sustainable food production. According to the raising environmental impacts effected with unsustainable agricultural production, more researches are needed on the greenhouse gas (GHG) of agricultural products (Romero-Gámez et al. 2014). In agricultural activity, sustainability can be intended from various perspectives such as economic, energy and environmental. Energy 
consumption in agriculture has increased in recent years according the population growth and raising need for food. This has led to an increase GHG emissions and environmental deterioration. Wheat is one of the common cereals because of its adaptation to different climates (Liu et al. 2019). It is widely cultivated in Iran, mainly for its seed, and is a strategic production because wheat is popular cereals in the Iranian diet.

54 According to Tabatabaeefar et al. (2009) the relationship between the energy source and agricultural systems is close. Besides, energy consumption and environmental quality are mutually dependent (Alhajj Ali et al. 2013). Energy resources affect the environment, including climate pollution, damage to human health, and GHG emissions. Hence, high energy consumption leads to a deteriorating environment. The efficient use of energy leads to cost savings, reduction of GHG emissions and conservation of natural resources (NabaviPelesaraei et al. 2018). To achieve sustainable agriculture goals and improve energy use efficiency, energy and economic analysis are essential (Naderloo et al. 2012). In other word, it is necessary to study patterns of energy use in agricultural productions to select a sustainable and optimal model, reduce production costs and environmental pollution. Life cycle assessment (LCA) is a valuable procedure that is generally applied to assess and investigate the environmental aspects of products or their operations. It can be also applied to assess the agricultural systems sustainability (Fathollahi et al. 2018). LCA is generally utilized to estimate all direct and indirect environmental pollution of systems (Mohammadi et al. 2015). Global warming potential (GWP), which is result from greenhouse gas emissions is one of the basic environmental indicators. The energy consumption pattern varies according to management and agricultural systems, climate, and other conditions; therefore one of the momentous steps to meet sustainable agriculture goals is determining the relationship between outputs and inputs in agricultural production processes (Naderloo et al. 2012). The focus of production functions is on the 
74 efficient allocation of resources (Ghasemi-Mobtaker et al. 2012). Models can also predict the environmental effects of agricultural systems, therefore, they are considered as an important tool for best management (Nabavi-Pelesaraei et al. 2018).

In recent years, several mathematical methods have been used to examine the relationship between inputs consumption and agricultural production (Singh et al. 2007; Abdi et al. 2012; Salehi et al. 2014; Antanasijević et al. 2015; Kaab et al. 2019a). In addition to mathematical methods, artificial neural networks (ANNs) are a strong and accurate tool for forecasting the performance of various systems (Taki et al. 2012b).

The main aim of the ANNs techniques is to solve solution in the same method that intelligence would. ANNs can be used to model and estimate different factors such as output energy, economical index, and GHG emissions (Kaab et al. 2019a). Taki et al (2012b) developed various ANNs to predict the energy output of corn silage cultivation in Iran. In another study, ANNs methodology was used to predict the greenhouse inside temperature in a semi-solar greenhouse (Taki et al. 2016). Soltanali et al. (2017) used ANNs technique to model the energy flows in kiwifruit cultivation. Nabavi-Pelesaraei et al. (Nabavi-Pelesaraei et al. 2018) applied ANNs approach for forecast the output energy and environmental pollution of paddy farms in the north of Iran.

Another intelligent system for modeling and forecasting is an ANFIS (Nabavi-Pelesaraei et al. 2019). It is a favorable method for the interpretation of non-linear systems (Naderloo et al. 2012). Like ANNs methodology, ANFIS has outstanding learning and has been applied to solve different problems. In recent years many research have been performed about the use of ANFIS technique in agricultural production systems. A few of these researches are shown in Table 1. 
Table 1

A summary of the researches about the application of different modeling techniques in agricultural systems.

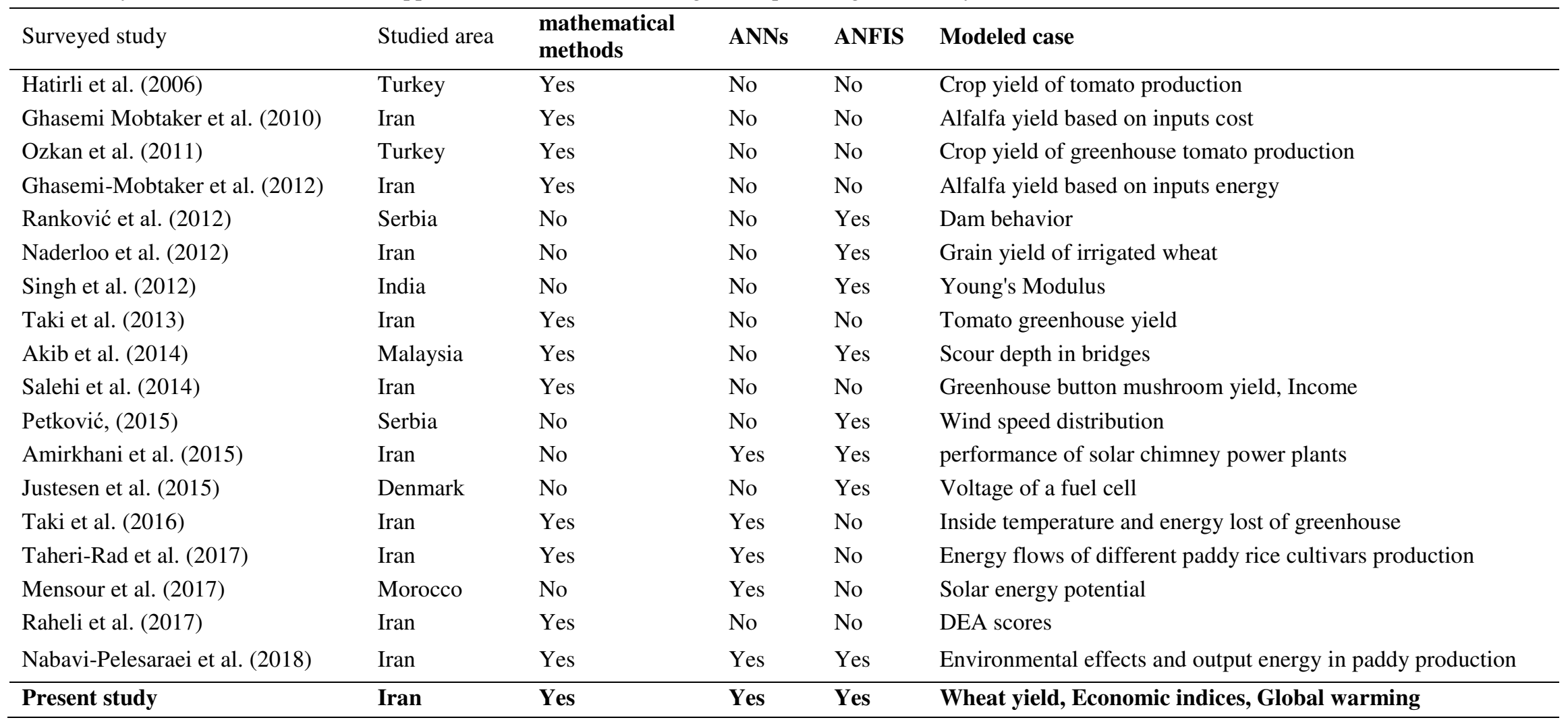


97 Given the above, the aim of this research was to assess the wheat farms sustainability in Iran.

98 For that achieve this aim, the following main steps have been considered:

99 - Studying energy consumption model and economic indices in wheat farms.

100 - Investigation of GHG emission in wheat farms using the LCA approach.

101 - Developing linear regression (LR), ANNs, and ANFIS models to predict energy use, 102 economic profit, and global warming in wheat cultivation.

103 - Evaluation of the mentioned models to specify the best pattern with consideration of $104 \quad$ sustainability development in wheat farms.

\section{2. Methodology and data}

106 2.1. Sampling design and geographical status

107 This research was performed in Hamedan state of Iran; which the geographical location is 108 located of $33^{\circ} 59^{\prime}$ and $35^{\circ} 48^{\prime} \mathrm{N}$ and $47^{\circ} 34^{\prime}$ and $49^{\circ} 36^{\prime} \mathrm{E}$ (Ministry of Jihad-e-Agriculture of 109 Iran 2019). The location of the study area shows in Fig. 1. The data requirement was collected 110 from 75 wheat farms using questionnaires and interviews. The inputs data include, diesel 111 fuel, biocides, etc. and the economic data include inputs cost and different operations cost. In

112 this study considering Cochran's sample size formula and using simple random sampling

113 technique, the suitable size of sample was calculated (Ghasemi-Mobtaker et al. 2012):

$$
\mathrm{n}=\frac{\mathrm{N}(\mathrm{s} \times \mathrm{t})^{2}}{(\mathrm{~N}-1) \mathrm{d}^{2}+(\mathrm{s} \times \mathrm{t})^{2}}
$$

114 Where, $n$ and $N$ is the sample and population size, respectively, $s$ is the $\mathrm{SD}, t$ is the $\mathrm{t}$ value at

$11595 \%$ confidence limit (1.96) and $d$ is the permissible error (5\%). 


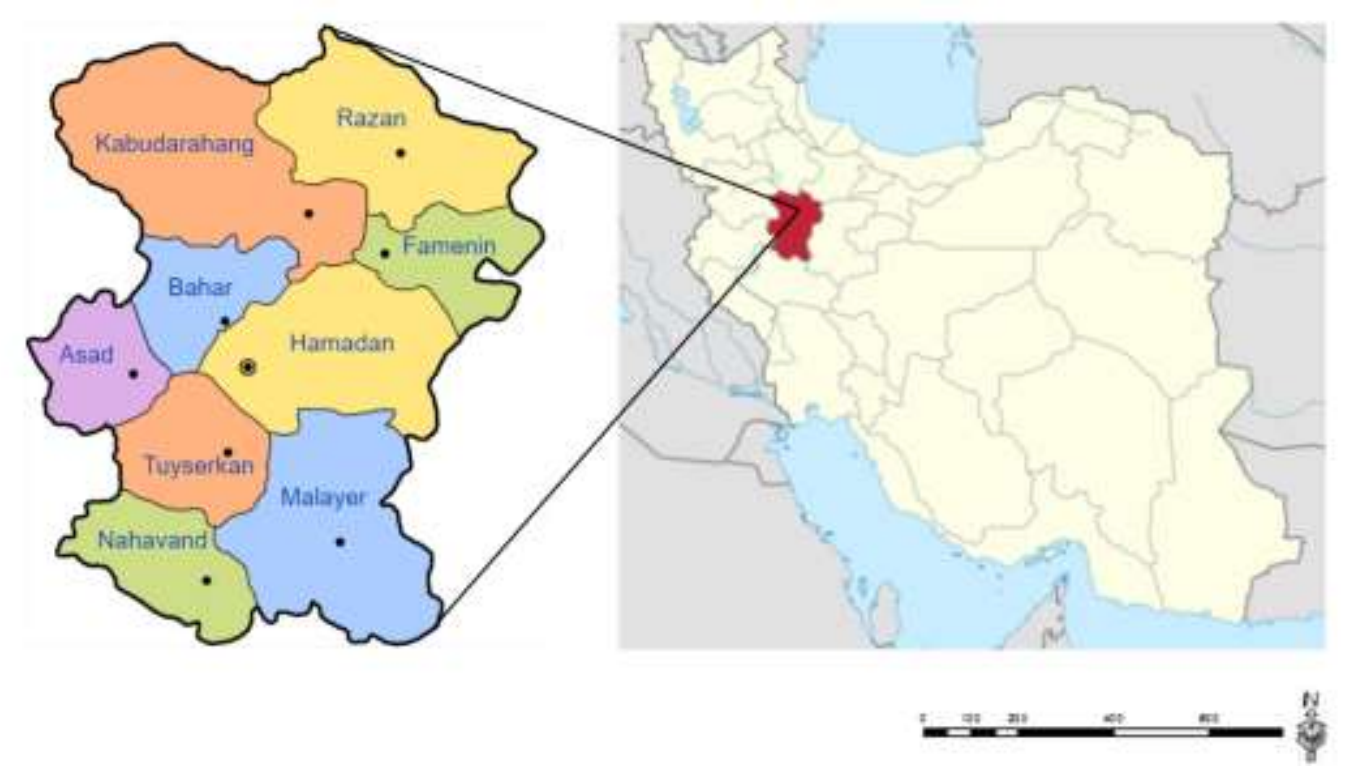

Fig. 1. Geographical location of the Hamedan province

116

\section{2.2. Energy Input-output and economic performance}

118 In the case of wheat cultivation, energy input resources contain human labor, machines,

119 fertilizers, diesel fuel, biocides, electricity and seed. The energy output resource including

120 wheat grain and straw. Table 2 demonstrates the energy coefficients equivalent of different

121 inputs/outputs in wheat cultivation.

Table 2

Inputs-outputs energy equivalent in wheat cultivation.

\begin{tabular}{|c|c|c|c|c|}
\hline Items & & Units & Energy equivalent (MJ unit ${ }^{-1}$ ) & Reference \\
\hline \multirow{10}{*}{ Inputs } & 1. Human labour & $\mathrm{h}$ & 1.96 & (Tabatabaeefar et al. 2009) \\
\hline & 2. Machines & $\mathrm{kg}$ & 62.70 & (Raheli et al. 2017) \\
\hline & 3. Diesel fuel & $\mathrm{L}$ & 56.31 & (Ghasemi-Mobtaker et al. 2010) \\
\hline & 4. Total fertilizer & & & \\
\hline & (a) Nitrogen & $\mathrm{kg}$ & 66.14 & (Zangeneh et al. 2010) \\
\hline & (b) Phosphate $\left(\mathrm{P}_{2} \mathrm{O}_{5}\right)$ & $\mathrm{kg}$ & 12.44 & (Zangeneh et al. 2010) \\
\hline & (c) Manure & $\mathrm{kg}$ & 0.30 & (Mohammadi et al. 2014) \\
\hline & 5. Biocides & $\mathrm{kg}$ & 120 & (Canakci et al. 2005) \\
\hline & 6. Electricity & $\mathrm{kWh}$ & $11.93^{*}$ & (Ghasemi-Mobtaker et al. 2012) \\
\hline & 7. Seed & $\mathrm{kg}$ & 14.7 & (Ozkan et al. 2004) \\
\hline Outputs & 1. Wheat grain yield & $\mathrm{kg}$ & 14.7 & (Ozkan et al. 2004) \\
\hline
\end{tabular}


${ }^{*}$ This coefficient used according to the efficiency of power plants and power loss of distribution networks reported in references for Iran.

122 During the wheat production period, the input energies associated with agricultural

123 machinery in $\mathrm{MJ} \mathrm{kg}^{-1}$ are determined by considering the weight of depreciated machinery per

124 hectare as shown in Eq. (2) (Ghasemi-Mobtaker et al. 2020a):

$$
T W=\frac{G \times W_{h}}{T}
$$

125 where $T W$ is the depreciated weight of machinery $\left(\mathrm{kg} \mathrm{ha}^{-1}\right), G$ is the total machine weight

$126(\mathrm{~kg}), W_{h}$ is the used time of machine per hectare $\left(\mathrm{h} \mathrm{ha}^{-1}\right)$ and $T$ is the machine economical

127 lifetime (h).

128 The economic analysis of wheat production is also has been researched. For this aim, the net

129 return, a benefit to cost ratio, and productivity are calculated. The total cost of wheat

130 production comprises both variable and fixed costs. The variable costs include costs of used

131 materials such as electricity, diesel fuel, and others in addition to operating costs whilst the

132 fixed costs are mainly the rental cost of 1 ha wheat farm. Data costs are computed for one ha

133 and employed to determine various economic indices. These indices showed in Eqs. (3)-(5)

134 (Salehi et al. 2014; Ghasemi-Mobtaker et al. 2020b)

Net return $\left(\$ h^{-1}\right)=$ Total production value $\left(\$ \mathrm{ha}^{-1}\right)-$ Total production costs $\left(\$ \mathrm{ha}^{-1}\right)$

Benefit - cost ratio $=\frac{\text { Total production value }\left(\$ \mathrm{ha}^{-1}\right)}{\text { Total production costs }\left(\$ \mathrm{ha}^{-1}\right)}$

Productivity $\left(\mathrm{kg} \$^{-1}\right)=\frac{\text { Wheat grain yield }\left(\mathrm{kg} \mathrm{ha}^{-1}\right)}{\text { Total production costs }\left(\$ \mathrm{ha}^{-1}\right)}$

\subsection{LCA framework}

136 LCA, also known as Eco balance, and cradle-to-grave analysis is a technique to assess

137 environmental impacts associated with all the stages of a product's life from raw material

138 extraction through materials processing, manufacture, distribution, use, repair and 
139 maintenance, and disposal or recycling. Designers use this process to help critique their

140 products. LCAs can help avoid a narrow outlook on environmental concerns by (Tonini and

141 Astrup 2012; Kaab et al. 2019b). Compiling an inventory of relevant energy and material

142 inputs and environmental releases;

143 - Evaluating the potential impacts associated with identified inputs and releases;

144 - Interpreting the results to help in making a more informed decision.

145 According to this pattern, LCA consists of the following four sections: (1) Goal and scope

146 definition, (2) Life cycle inventory (LCI), (3) Life cycle impact assessment (LCIA), (4) Life

147 cycle interpretation (Kaab et al. 2019a; Mostashari-Rad et al. 2021).

\section{2.3.1. Definition of goal and scope}

149 Definition of goal and scope are a significant key to constitute the overall framework that 150 includes functional unit (FU), system boundaries, resource allocation, and sector selection 151 effect (Curran 2017). Fig. 2 presented the schematic design boundaries of the system for 152 wheat farms. The wheat cultivation includes land preparation, spreading farmyard manure on 153 the field, seed planting, irrigation, fertilizing, spraying, and harvesting using a self-propelled 154 combine. FU is considered as one ton of product in this study, which means that all released 155 contaminants are computed and reported based on user inputs to produce a product (Chang et 156 al. 2014). 


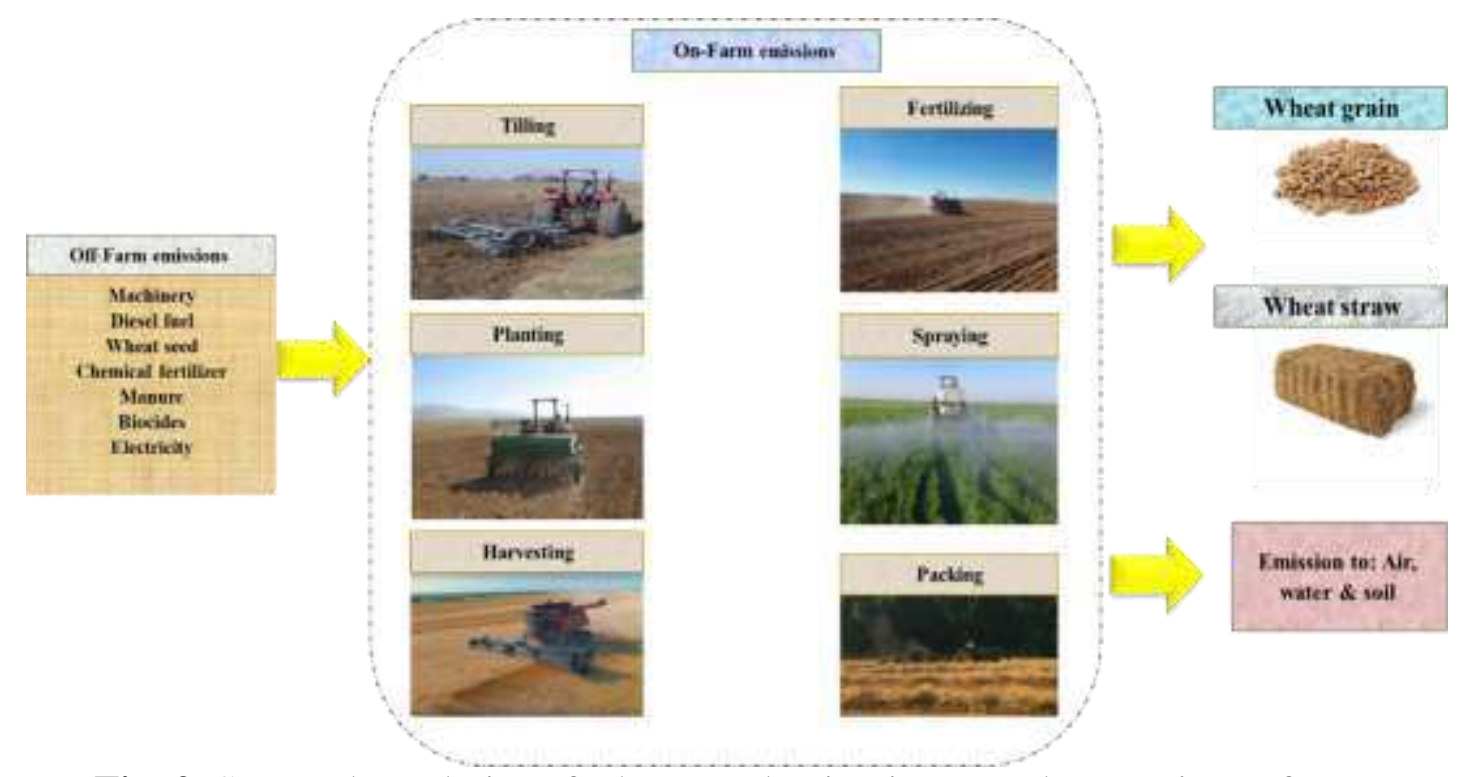

Fig. 2. System boundaries of wheat production in Hamedan province of Iran.

157

158 2.3.2. LCI analysis

159 LCI analysis involves creating an inventory of flows from and to nature for a product system

160 (Mälkki and Alanne 2017). Inventory flows include inputs of water, energy, and raw

161 materials, and releases to air, land, and water (Hasler et al. 2015). To develop the inventory, a

162 flow model of the technical system is constructed using data on inputs and outputs. The flow

163 model is typically illustrated with a flowchart that includes the activities that are going to be

164 assessed in the relevant supply chain and gives a clear picture of the technical system

165 boundaries (Recanati et al. 2018). The input and output data needed for the construction of

166 the model are collected for all activities within the system boundary, including from the

167 supply chain. In the present study, the system inputs include actual farm practices and

168 resource consumption, which were collected through face-to-face questionnaires and farm

169 visits, and the outputs were wheat grain and straw yield. 
171 Following the LCI is the LCIA. This stage is purposed at assessing the important of possible environmental effects results according to the LCI (Cavalliere et al. 2018). LCIA is a classic

173 of the following compulsory principle (Grados and Schrevens 2019):

174 - Choice of environmental categories, indices of category, and models of 175 characterization.

176 - The classification stage, in which mass inventory components are classified and affected by particular categories.

- The evaluation of impact, where the LCI flow is classified applying one of the many feasible LCIA techniques, to the common equivalence units in which, to aggregate the total impact classification.

In previous studies, various techniques have been used to assess environmental impacts. For instance, the CML 2 baseline technique was used in LCA research of agricultural system. In this research, the CML-IA base V3.05/Netherlands, 1997 technique simultaneously with are

184 applied with the related eleven effects categories.

\subsection{Linear regression}

186 Linear regression in statistics is a linear method for modeling the communication among one

187 or more independent variables and dependent variable. Simple linear regression is called an 188 independent variable (Meng et al. 2015). Furthermore, multiple linear regressions are called

189 one independent variable. This term is different from a single-scale variable with multivariate

190 linear regression, in which several correlated dependent variables are forecasted. Linear

191 regression was the first type of regression analysis that was carefully studied and applied in 192 applicable utilization (Estelles-Lopez et al. 2017). This is because the models that are linear 193 in the unknown parameters themselves are dependent on the models that are nonlinear 
194 parameters are not relevant, easier since fall and because the statistical properties of estimators they are simpler than summarizing (Ali and Deo 2020).

196

In this study, regression analysis is used to analyze and determine the communication

197 between the response variable and explanatory variable. The variables considered for analysis

198 in this research are ten inputs including human labor $\left(\mathrm{X}_{1}\right)$, machinery $\left(\mathrm{X}_{2}\right)$, nitrogen $\left(\mathrm{X}_{3}\right)$,

199 phosphate $\left(\mathrm{X}_{4}\right)$, manure $\left(\mathrm{X}_{5}\right)$, diesel fuel $\left(\mathrm{X}_{6}\right)$, biocides $\left(\mathrm{X}_{7}\right)$, water $\left(\mathrm{X}_{8}\right)$, seed $\left(\mathrm{X}_{9}\right)$ and electricity $\left(\mathrm{X}_{10}\right)$. Seven outputs including yield (wheat grain and straw), output energy (wheat grain and straw), total production value, net return, and GWP are a dependent variable.

Equations (6-12) applied for wheat production is shown as follows:

$$
\begin{aligned}
& \text { Wheat grain yield }=e_{i}+\alpha_{1} X_{1}+\alpha_{2} X_{2}+\alpha_{3} X_{3}+\alpha_{4} X_{4}+\alpha_{5} X_{5}+\alpha_{6} X_{6}+\alpha_{7} X_{7}+\alpha_{8} X_{8}+\alpha_{9} X_{9}+\alpha_{10} X_{10} \\
& \text { Wheat straw yield }=e_{i}+\beta_{1} X_{1}+\beta_{2} X_{2}+\beta_{3} X_{3}+\beta_{4} X_{4}+\beta_{5} X_{5}+\beta_{6} X_{6}+\beta_{7} X_{7}+\beta_{8} X_{8}+\beta_{9} X_{9}+\beta_{10} X_{10} \\
& \text { Output energy (grain) }=e_{i}+\lambda_{1} X_{1}+\lambda_{2} X_{2}+\lambda_{3} X_{3}+\lambda_{4} X_{4}+\lambda_{5} X_{5}+\lambda_{6} X_{6}+\lambda_{7} X_{7}+\lambda_{8} X_{8}+\lambda_{9} X_{9}+\lambda_{10} X_{10} \\
& \text { Output energy (straw) }=e_{i}+\omega_{1} X_{1}+\omega_{2} X_{2}+\omega_{3} X_{3}+\omega_{4} X_{4}+\omega_{5} X_{5}+\omega_{6} X_{6}+\omega_{7} X_{7}+\omega_{8} X_{8}+\omega_{9} X_{9}+\omega_{10} X_{10} \\
& \text { Total production value }=e_{i}+\eta_{1} X_{1}+\eta_{2} X_{2}+\eta_{3} X_{3}+\eta_{4} X_{4}+\eta_{5} X_{5}+\eta_{6} X_{6}+\eta_{7} X_{7}+\eta_{8} X_{8}+\eta_{9} X_{9}+\eta_{10} X_{10} \\
& \text { Net return }=e_{i}+v_{1} X_{1}+v_{2} X_{2}+v_{3} X_{3}+v_{4} X_{4}+v_{5} X_{5}+v_{6} X_{6}+v_{7} X_{7}+v_{8} X_{8}+v_{9} X_{9}+v_{10} X_{10} \\
& \text { GWP }=e_{i}+\varepsilon_{1} X_{1}+\varepsilon_{2} X_{2}+\varepsilon_{3} X_{3}+\varepsilon_{4} X_{4}+\varepsilon_{5} X_{5}+\varepsilon_{6} X_{6}+\varepsilon_{7} X_{7}+\varepsilon_{8} X_{8}+\varepsilon_{9} X_{9}+\varepsilon_{10} X_{10}
\end{aligned}
$$

\subsection{ANNs model}

The basic tools applied in machine learning are called ANNs (Kalogirou and Bojic 2000). As part of the neural their names indicate, they are inducted by the brain systems that seek to the way we humans learn reproduction (Zangeneh et al. 2011).

207 The neural networks include input, output and hidden layers which including of units that

208 convert input into something that the output layer can apply (Nabavi-Pelesaraei et al. 2014).

They are a great tool for finding schema that are too complex for a human programmer to recognize and train the device (Taheri-Rad et al. 2017). ANNs are based on a set of jointed 
211 units named artificial neurons that easily design neurons action in the brain (Taki et al.

212 2012a). Like the brain synapses, any nexus can transfer a signal to other nerve cells. Each

213 neuron receives a signal, processes it and then transfer a signal to other nerve cells

214 (Khoshnevisan et al. 2013). In this research, the networks are built with ten inputs and seven

215 outputs (mentioned in section 2.4). For ANN-supervised training, the data were randomly

216 separated into three parts, including, training (70\%), testing (15\%) and validation (15\%).

\section{2.6. ANFIS model}

218 ANFIS is an ANN-based fuzzy inference system (Ahmed and Shah 2017). The method was

219 introduced in the early 1990s. As regards it combined both fuzzy logic principles and neural

220 networks, this has the possible to benefit both use a single framework (Naderloo et al. 2012).

221 Its inference system corresponds to a set of fuzzy If/Then statements which have learning

222 ability to proximate nonlinear functions (Khoshnevisan et al. 2014). Therefore, ANFIS is

223 introduced as a comprehensive estimator. Applying the ANFIS more efficiently and

224 optimally, it is possible to use the best parameters acquired by genetic algorithm (Mousavi-

225 Avval et al. 2017). For determine nodes in a ANFIS structure and nodes in a similar layer,

226 there are five layers that have the same function. Fig. 3 shows the structure, where in circles

227 and squares are marked by fixed nodes and adaptive, respectively. 


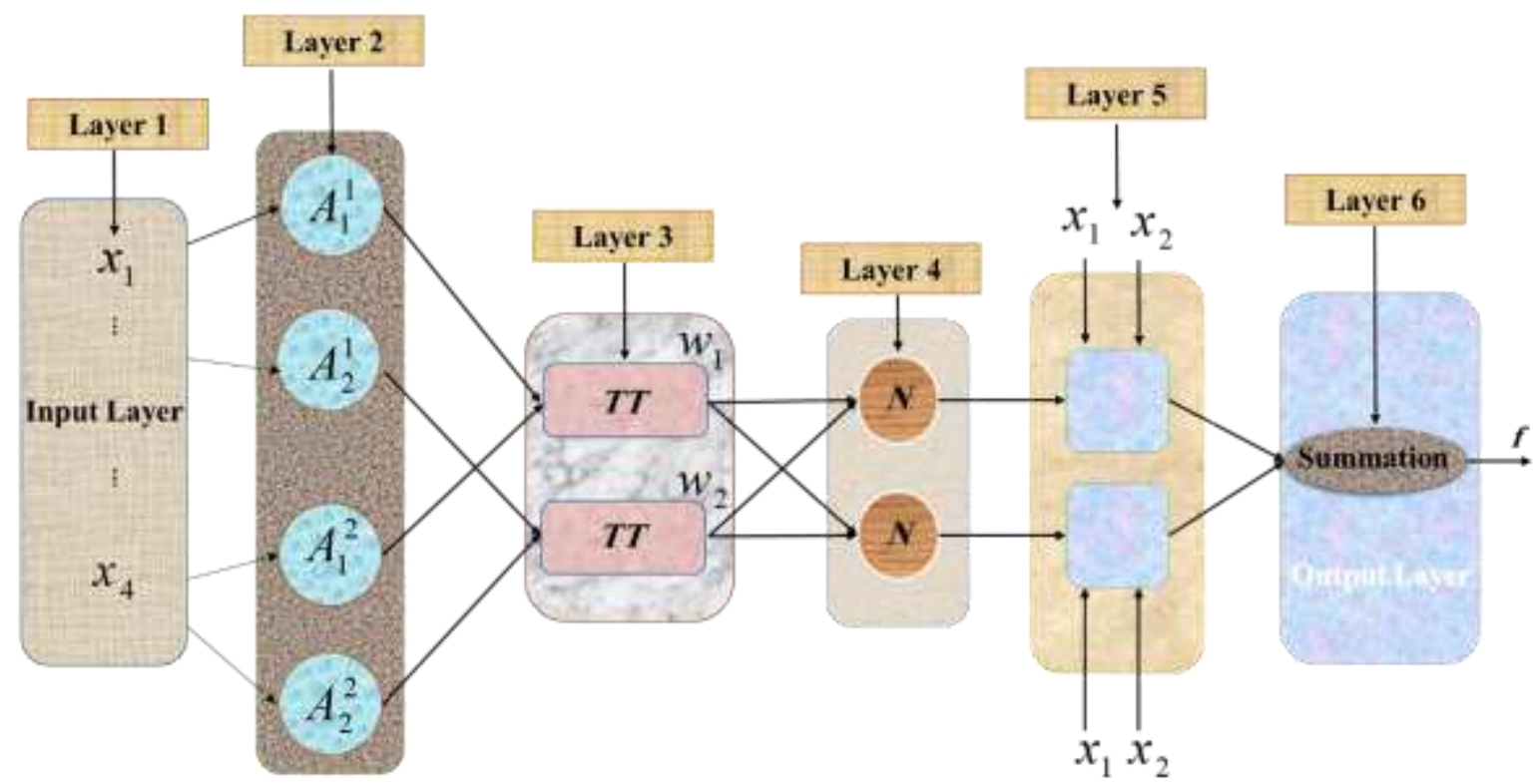

Fig. 3. The ANFIS model structure.

228 In this study, by classifying ten input variables in five clusters first and then into two clusters,

229 the clustering method has been used. Fig. 4 showed three-level ANFIS are developed, in total 230 eight ANFIS sub-networks.

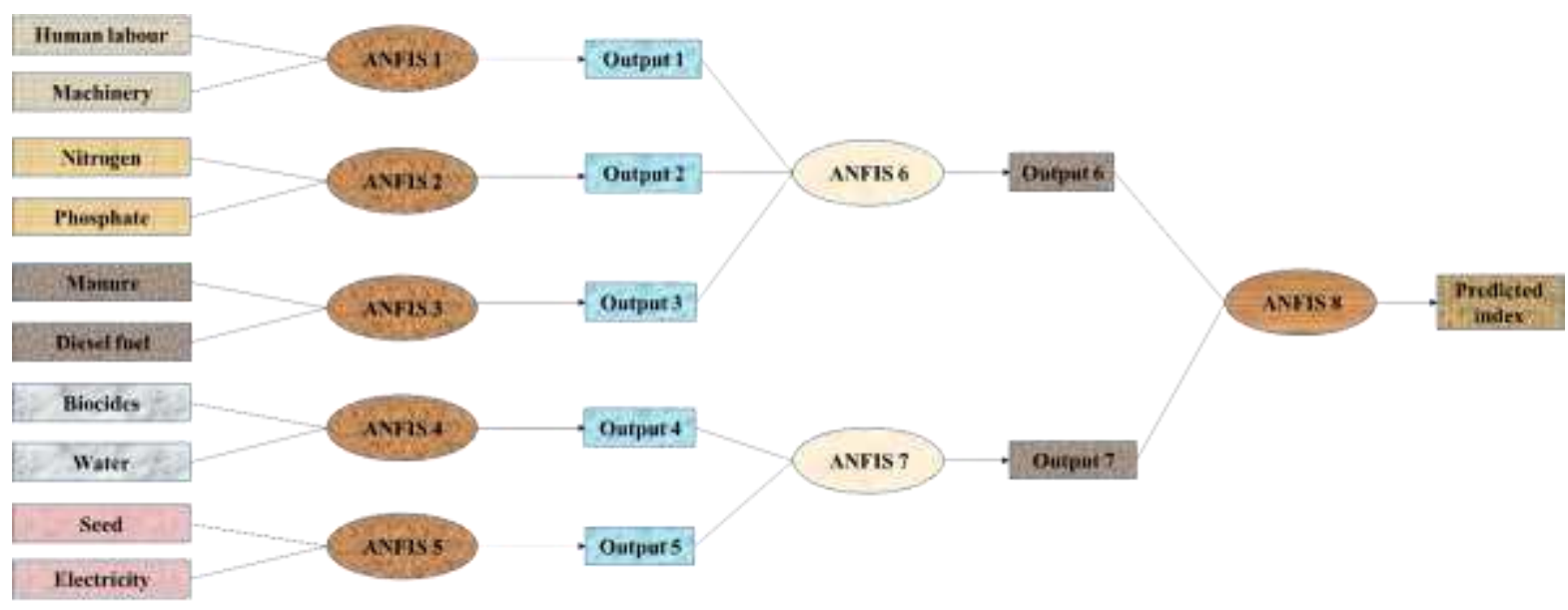

Fig. 4. 3-level ANFIS structure to forecast wheat yield, economical profit, and GWP of wheat cultivation. 
233 Differences between observed data and calculated LR, ANFIS and ANN models results are

234 applied to evaluate performance. Several statistical metrics, namely, coefficient of 235 determination $\left(\mathrm{R}^{2}\right)$, relative root mean square error (RRMSE) and root mean square error 236 (RMSE) according to Eqs. (6)-(8) used to evaluate the performance of models (Amirkhani et 237 al. 2015).

$R^{2}=1-\sqrt{\frac{\sum_{i=1}^{n}\left(P_{i}-A_{i}\right)^{2}}{\sum_{i=1}^{n} A_{i}^{2}}}$

RRMSE $=\frac{\sqrt{\frac{1}{n} \sum_{i=1}^{n}\left(P_{i}-A_{i}\right)^{2}}}{\sum_{i=1}^{n} P_{i}} \times 100$

$\mathrm{RMSE}=\sqrt{\frac{1}{\mathrm{n}} \sum_{i}^{n}\left(P_{i}-A_{i}\right)^{2}}$

238 Where $P_{i}$ denote the observed, $A_{i}$ modeled output for the ith training vector, and $n$ denotes

239 the quantity of training vectors.

$240 \quad$ 2.8. Applied software

241 By using Excel spreadsheets the energy input-output and economic indices are computed.

242 SimaPro V9.0.0.29 is applied to perform LCA. For applying linear regression, Payton

243 software package is employed and for ANNs and ANFIS analysis, Matlab software is used.

244 3. Results and discussion 
246 Table 3 presents the average of inputs/output energy in wheat cultivation calculated by

247 applying equivalent of energy in inputs and outputs as well as wheat economic indices. The

248 results revealed that around $43055 \mathrm{MJ} \mathrm{ha}^{-1}$ of energy is required for various processes in

249 wheat production. The amount of wheat grain and straw yield were about 5287 and $3175 \mathrm{~kg}$

$250 \mathrm{ha}^{-1}$, respectively. Accordingly, the average amount of the total output energy was computed

251 as $117407 \mathrm{MJ} \mathrm{ha}^{-1}$. Fig. 5 shows the percent of the energies input in wheat cultivation. The

252 mean of inputs energy consumption was highest for electricity (about 55\%) which is applied

253 in the irrigation system. This results are in agreement with the reported others studies

254 including (Singh et al. 2002), (Ghasemi-Mobtaker et al. 2012) and (Chen et al. 2019). In a

255 study that energy consumption for sugarcane production was investigated the electricity with

$25649 \%$ and $55 \%$ had the largest share in the total input energy in planted and ratoon farms,

257 respectively (Kaab et al. 2019a). The use of high-efficiency irrigation systems that use a

258 photovoltaic system to provide renewable electricity can reduce electricity use in wheat

259 cultivation. Furthermore the application of minimum tillage systems, use of residual crop

260 management as a green fertilizer and reduce use chemical fertilizers and also decrease the use

261 of biocides by applying the new techniques of spraying can enhance energy efficiency in

262 wheat cultivation.

Table 3

Inputs/outputs energy and economic indices in wheat cultivation.

\begin{tabular}{|c|c|c|c|}
\hline Items & Unit & Average & SD \\
\hline A. Energy inputs & $\mathrm{MJ} \mathrm{ha}^{-1}$ & & \\
\hline 1. Human labour & & 178.60 & 30.66 \\
\hline 2. Machinery & & 1195.15 & 184.96 \\
\hline 3. Diesel fuel & & 5726.73 & 750.37 \\
\hline \multicolumn{4}{|l|}{ 4. Chemical fertilizers } \\
\hline (a) Nitrogen & & 5851.63 & 2528.76 \\
\hline (b) Phosphate $\left(\mathrm{P}_{2} \mathrm{O}_{5}\right)$ & & 1001.86 & 433.82 \\
\hline (c) Manure & & 624.00 & 653.85 \\
\hline 5. Biocides & & 285.12 & 80.10 \\
\hline
\end{tabular}




\section{Electricity \\ 7. Seed}

Total energy input

B. Energy outputs

1. Wheat grain

2. Wheat straw

Total energy output

\section{Economic indices}

\begin{tabular}{llll} 
Total value of wheat cultivation & $\$ \mathrm{ha}^{-1}$ & 854.86 & 158.28 \\
Total cost of wheat cultivation & $\$ \mathrm{ha}^{-1}$ & 366.57 & 43.64 \\
Benefit - cost ratio & - & 2.33 & 0.36 \\
Net return & $\$ \mathrm{ha}^{-1}$ & 488.29 & 141.19 \\
Productivity & $\mathrm{kg}^{-1}$ & 14.42 & 2.20 \\
\hline
\end{tabular}

$23534.59 \quad 6646.94$

$4656.96 \quad 510.60$

43054.63 8652.21

$\mathrm{MJ} \mathrm{ha}^{-1}$

$77723.80 \quad 14376.67$

$39683.33 \quad 9401.63$

$117407.13 \quad 22602.35$

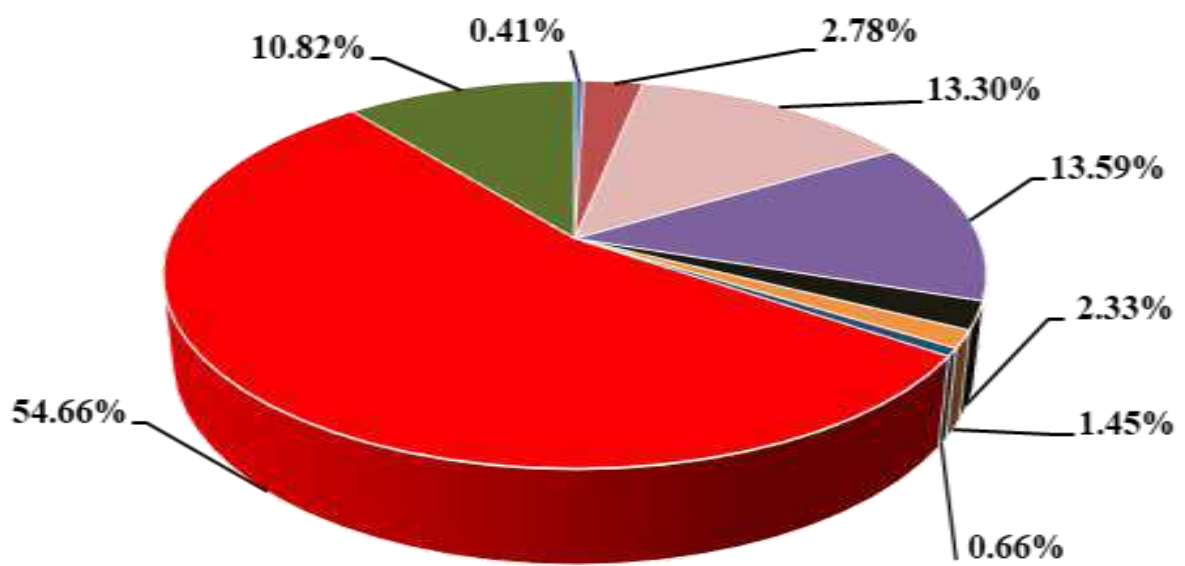

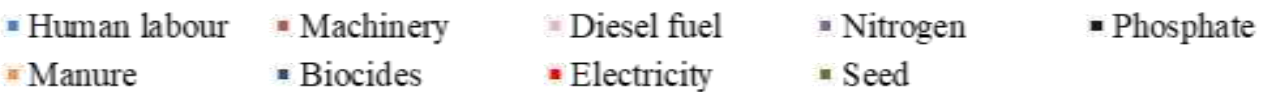

Fig. 5. The energy input quota for wheat production in study region.

264 Economic indicators in wheat cultivation are calculated using Eqs. (3)-(5) and the results are 265 listed in Table 3. The results demonstrated that the total wheat cultivation value was about $266855 \$ \mathrm{ha}^{-1}$. Using total cost and benefit of wheat cultivation, net return and benefit - cost ratio 267 was calculated as $488.29 \$ \mathrm{ha}^{-1}$ and 2.33 , respectively. Also, the productivity index was 268 calculated as $14.42 \mathrm{~kg} \$^{-1}$, indicating that about $14 \mathrm{~kg}$ of wheat was produced in the region 
269 for every spending dollar. In the study conducted in the northern Iran the net return indicator 270 in wheat production was about $627 \$ \mathrm{ha}^{-1}$ for the semi-mechanized systems, while in

271 mechanized systems this index was calculated as $994 \$$ ha $^{-1}$ (Amoozad-Khalili et al. 2020).

272 Fig. 6 displays the share of cost input for wheat production obtained from economic analysis.

273 The shares of irrigation (electricity and water) and human labour cost were around 33\% and

$27421 \%$, respectively, from the total expenditures. Similar study were showed in the literature 275 that the costs of water for irrigation were highest in the alfalfa farms (Ghasemi-Mobtaker et 276 al. 2012). The results also showed that inputs cost was least for manure and biocides which 277 accounted $1.9 \%$ and 2\%, respectively. Mohammadi et al. (2010a) investigated economical 278 indices for kiwifruit in the northern Iran and reported that human labour, renting and 279 fertilizers had the highest energy cost.

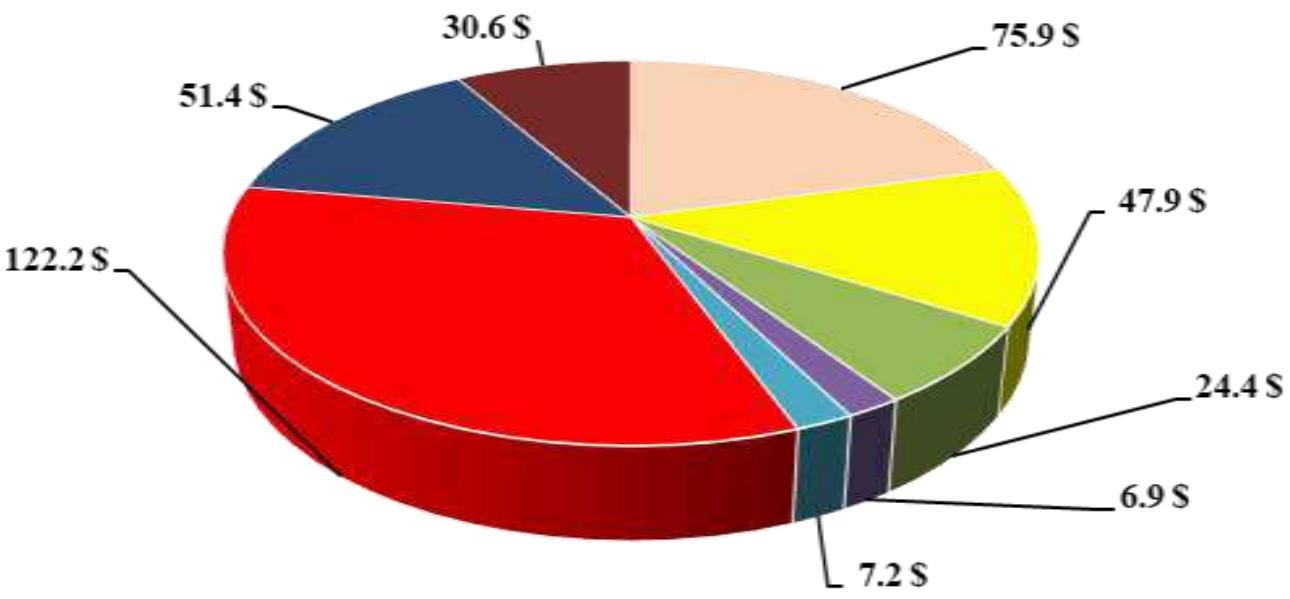

$\begin{array}{lll}\text { - Human labour } & \text { Machinery and Diesel fuel } & \text { - Chemical fertilizers } \\ \text { - Manure } & \text { Biocides } & \text { - Electricity and water } \\ \text { - Seed } & \text { Rent of land } & \end{array}$

Fig. 6. The percent of input costs for wheat cultivation in study region.

\subsection{LCA result interpretation}

281 The average environmental indexes were calculated for one ton of wheat production and

282 results illustrated in Table 4. Global warming is one of the most common environmental 283 indicators applied as an indicator to assess environmental sustainability in agricultural 
284 production. The results demonstrated that wheat cultivation in the study area causes to release 285 of $624.29 \mathrm{~kg} \mathrm{CO}_{2}$ eq. $\operatorname{ton}^{-1}$. In a research conducted in the north of Iran, this index was

286 reported as $291 \mathrm{~kg} \mathrm{CO}_{2}$ eq. ton $^{-1}$ for wheat cultivation (Soltani et al. 2013). In another study 287 on wheat production, the global warming index of irrigated farms was reported higher than 288 dryland farms (Mondani et al. 2017). Khakbazan et al. (2009) reported that according to 289 cultivation place, the rate of fertilizer consumption and planting system, emissions of 290 greenhouse gas for wheat cultivation were in the range of $410-1130 \mathrm{~kg} \mathrm{CO}_{2}$ eq ha ${ }^{-1}$. In 291 another study the emission amount for potato production was reported to be $2350 \mathrm{~kg} \mathrm{CO}_{2}$ eq $292 \mathrm{ha}^{-1}$ (Ferreira et al. 2011).

Table 4

The average environmental indexes in wheat cultivation.

\begin{tabular}{llll}
\hline Impact categories (Nomenclature) & Unit & Average & SD \\
\hline Abiotic depletion (AD) & $\mathrm{kg} \mathrm{Sb}$ eq. & 0.0028 & 0.0006 \\
Abiotic depletion of fossil fuels (ADF) & $\mathrm{MJ}$ & 6673.1319 & 1598.0940 \\
Global warming (GWP) & $\mathrm{kg} \mathrm{CO}_{2}$ eq. & 624.2944 & 129.9279 \\
Ozone layer depletion (OLD) & $\mathrm{kg} \mathrm{CFC-11} \mathrm{eq.}$ & 0.0001 & 1.3002 \\
Human toxicity (HT) & $\mathrm{kg} \mathrm{1,4-DB}$ eq. & 229.1000 & 42.7028 \\
Freshwater aquatic ecotoxicity (FE) & $\mathrm{kg} \mathrm{1,4-DB}$ eq. & 173.2949 & 34.0226 \\
Marine aquatic ecotoxicity (ME) & $\mathrm{kg} \mathrm{1,4-DB} \mathrm{eq.}$ & 319757.6377 & 60168.7216 \\
Terrestrial ecotoxicity (TE) & $\mathrm{kg} \mathrm{1,4-DB} \mathrm{eq.}$ & 12.7851 & 2.7699 \\
Photochemical oxidation (PO) & $\mathrm{kg} \mathrm{C}_{2} \mathrm{H}_{4}$ eq. & 0.1202 & 0.0268 \\
Acidification (AC) & $\mathrm{kg} \mathrm{SO}_{2}$ eq. & 7.6978 & 3.8658 \\
Eutrophication (EP) & $\mathrm{kg} \mathrm{P}_{4}^{-3}$ eq. & 2.6710 & 0.9496 \\
& & & \\
\hline
\end{tabular}

293 The normalized distribution of different inputs in one ton of wheat yield is illustrated in Fig.

294 7. According to the results of normalization, ME category has the highest environmental 295 effect in wheat cultivation, where in the significant contribution is related to chemical 296 fertilizer. Soltanali et al. (2017) related that gasoline and fertilizer as the main cause of high 297 field emissions for agricultural products. Fathollahi et al. (2018) calculated On-Farm 298 emissions of corn silage to $\mathrm{EP}$ whose value was equal to $2.73 \mathrm{~kg} \mathrm{PO}_{4 \mathrm{eq}} \mathrm{t}^{-1}$. Kaab et al. (2019a) cited ME levels for plant farms (51636.91 kg 1,4-DB eq.) and ratoon farms (35448.06 
$300 \mathrm{~kg} \mathrm{1,4-DB}$ eq.) as the most substantial impacts to this section. As shown in Fig. 7, the results

301 of normalized confirm on proper management of fertilizer utilization to reduce the

302 environmental effects of chemical fertilizer production in wheat production. The use of 303 conservation tillage methods to improve soil structure as well as the use of organic fertilizers

304 to increase soil organic matter can be an effective step in decreasing the application of 305 fertilizers.

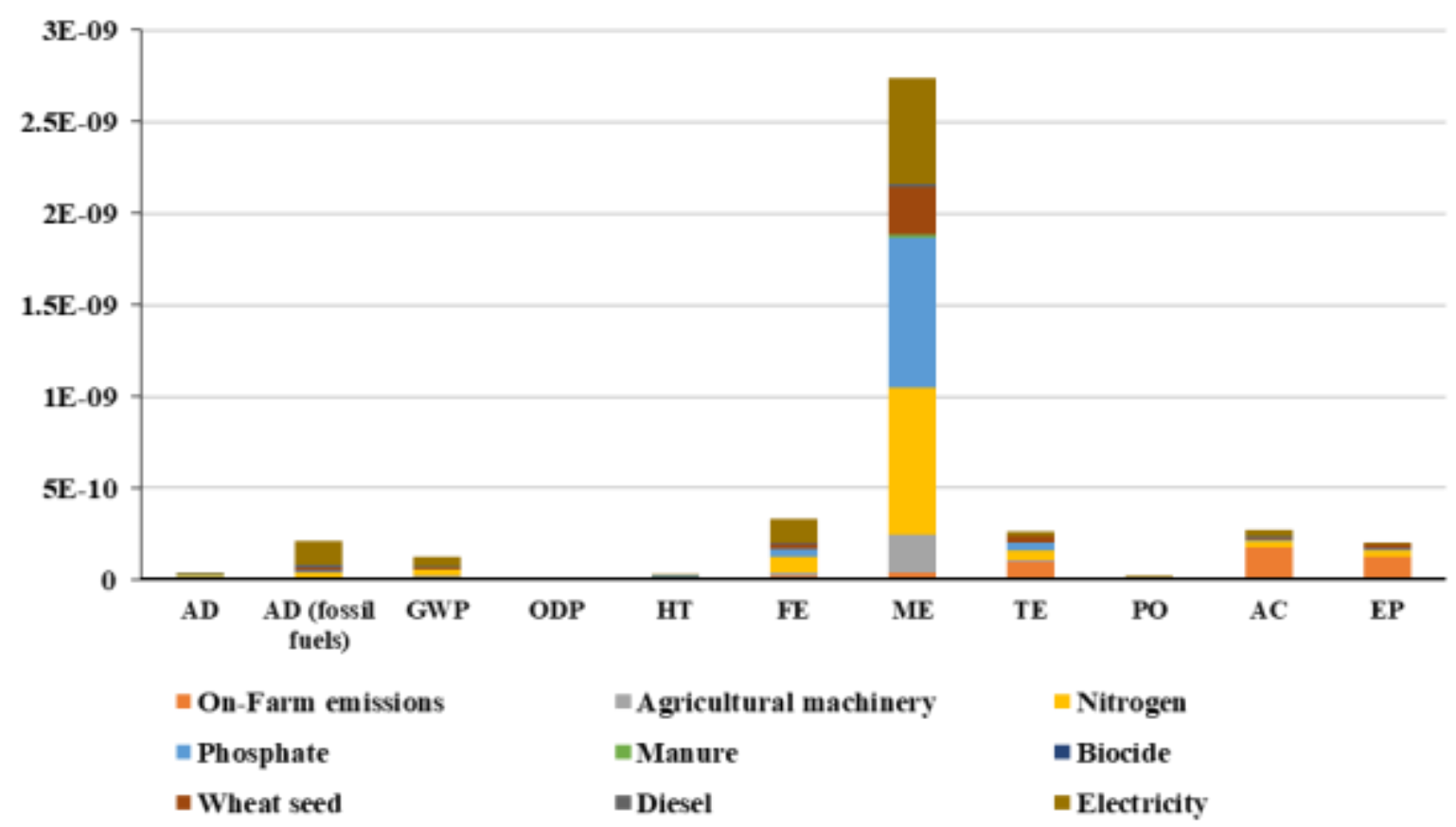

Fig. 7. Normalization of different inputs in the environmental impact categories for wheat production.

\subsection{Evaluation of linear regression}

307 The linear regression analysis is applied to determine the communication between outputs

308 and inputs of wheat cultivation in this research. The independent variables considered for

309 analysis in this research are ten inputs applied in wheat cultivation (mentioned in table 3) and

310 the depended variables are seven outputs including yield (wheat grain and straw), output

311 energy (wheat grain and straw), total production value, net return, and GWP. Based on Eq.

312 (6) to Eq. (12) for all investigated models regression coefficients and statistics indices are

313 calculated using Payton software package. 
315 The regression coefficients for Eqs. (6)-(12) were estimated and the results are as below:

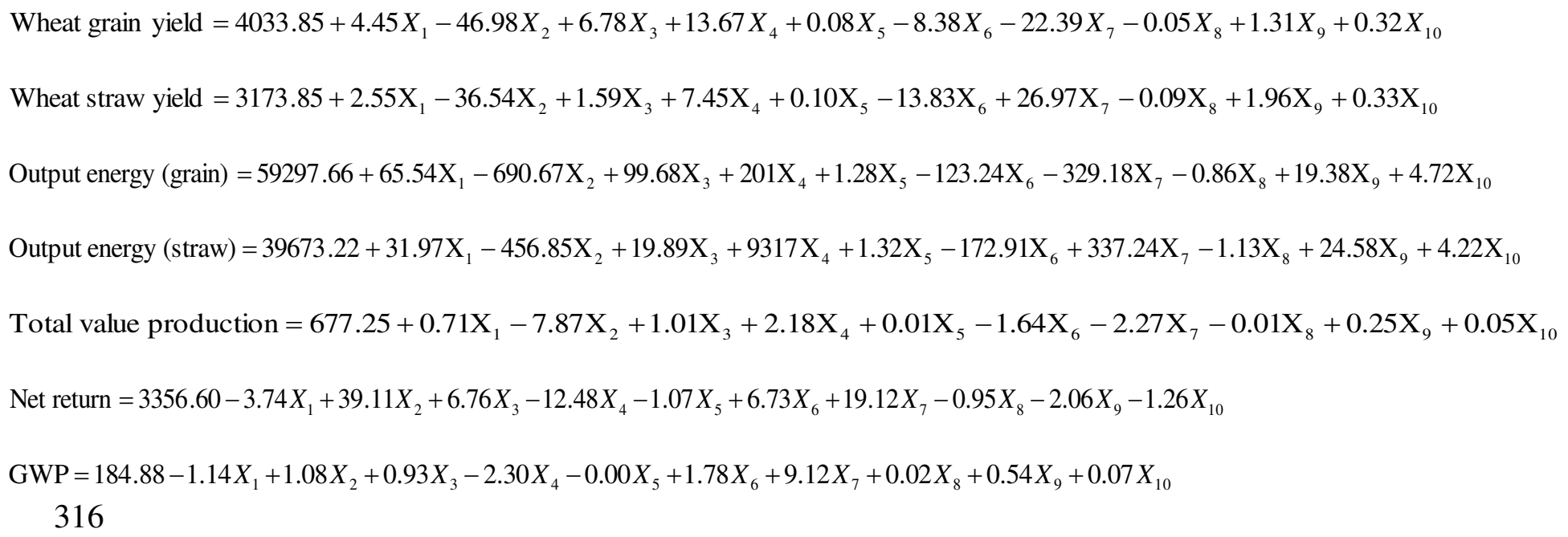

317 Wheat grain yield: phosphate, nitrogen, and human labor are major inputs that have a

318 positive effect, whereas machinery, biocides, and diesel fuel are major inputs that have a

319 negative effect on wheat grain yield.

320 Wheat straw yield: biocides, phosphate, and human labor are major inputs that have a

321 positive effect on wheat straw yield; whereas machinery and diesel fuel are major inputs that

322 have a negative effect on wheat straw yield.

323 Output energy (grain): nitrogen, phosphate, and human labor are major inputs that have a

324 positive effect on wheat grain energy; whereas machinery, biocides, and diesel fuel are major

325 inputs that have a negative effect on wheat grain energy.

326 Output energy (straw): phosphate and biocides are major inputs that have a positive effect

327 on wheat straw energy; whereas machinery and diesel fuel are major inputs that have a

328 negative effect on wheat grain energy.

329 Total value production: phosphate and nitrogen are major inputs that have a positive effect

330 on total value production; whereas machinery, biocides, and diesel fuel are major inputs that 331 have a negative effect on total value production. 
332 Net return: machinery and biocides are major inputs that have a positive; whereas phosphate

333 is a major input that has a negative effect on net return.

334 GWP: biocides and diesel fuel are major inputs that have a positive effect on GWP; whereas

335 phosphate and human labor are major inputs that have a negative effect on net return.

\subsubsection{Evaluation of model by linear regression}

337 Statistical parameters of the different models in predicting yield, economic profit, and global

338 warming in wheat farms are shown in table 5. According to the table, the $\mathrm{R}^{2}$ vary in the range 339 of 0.264 to 0.978 . The $\mathrm{R}^{2}$ value for net return predicting was determined as 0.978 , indicating

340 that this model can explain about 0.98 of the variability in the net return. For this model,

341 RMSE and RRMSE were computed to be 460.616 and 0.033 , respectively; which indicates

342 the best capability of this model in predicting the net return of wheat cultivation.

Table 5

The results of different models arrangements by linear regression.

\begin{tabular}{llll}
\hline Independent variables & \multicolumn{3}{l}{ Statistics indices } \\
\cline { 2 - 4 } & $\mathrm{R}^{2}$ & RMSE & RRMSE \\
\hline Wheat grain yield & 0.677 & 551.433 & 0.104 \\
Wheat straw yield & 0.438 & 559.866 & 0.176 \\
Output energy (grain) & 0.677 & 8106.065 & 0.104 \\
Output energy (straw) & 0.438 & 6998.327 & 0.176 \\
Total value production & 0.661 & 92.008 & 0.107 \\
Net return & 0.978 & 460.616 & 0.033 \\
GWP & 0.264 & 110.657 & 0.171 \\
\hline
\end{tabular}

\subsection{Evaluation of ANNs}

344 The statistical Indicators of the best ANN models in forecasting global warming and outputs

345 of wheat production are listed in Table 6. In this research Matlab software was used to model

346 implementation and data training and for all models, statistical metrics including $\mathrm{R}^{2}$, RMSE,

347 and RRMSE were calculated. For the ANN models multilayer neural networks with a

348 Levenberg-Marquardt (LM) algorithm were used. The results indicated that for wheat farms,

349 the $\mathrm{R}^{2}$ vary in ranges of 0.236 to 0.956 for the training stage, 0.332 to 0.933 for the testing stage, and 0.278 to 0.954 in overall. The best ANN structures for independent variables are 
351 also listed in Table 6. The results indicated that the structure with two hidden layers is the 352 best ANN structure in all models.

353 In the previous studies ANN has been used to predict of various factors; for example output 354 energy of corn silage (Taki et al. 2012b); environmental impact and yield of lentil cultivation 355 (Elhami et al. 2017); energy, economic and environmental effects of rice milling factories 356 (Nabavi-Pelesaraei et al. 2019); winter wheat yield (Chen and Jing 2017). ANN models used

357 to estimate yield and environmental impact in tea production with $\mathrm{R}^{2}$ values from 0.878 to 3580.990 (Khanali et al. 2017). Kaab et al. (2019a) utilized an ANN model to forecast output 359 energy generation and environmental impact in sugarcane cultivation. They reported that a 9$360 \quad 10-5-11$ structure (9 neurons in the input layer, 10 and 5 neurons in two hidden layers and 11 361 neurons in the output layer) is the best predictive ANN model for planted farms. Moreover, 362 for ratoon farms, the 7-9-6-11 structure had the best performance. The developed various 363 multilayer perception ANN models were applied to predict grape yield with respect to inputs 364 and was observed that the 7-6-1 architecture was the best model with the highest mean 365 correlation coefficient and the least standard deviation (Khoshroo et al. 2018). In another 366 study several ANNs models with different topologies and distinct learning algorithms was 367 used to modeling energy consumption in greenhouse tomato cultivation. The results showed 368 that the best prediction was obtained by the network topology of 10-20-7-9-1 with tangent

369 sigmoid and purelin transfer functions employed in hidden layers and the output layer, 370 respectively. Furthermore, the researchers found that, among the different training 371 algorithms, the LM algorithm produced the best result (Khoshnevisan et al. 2015).

\section{Table 6}

The results of different models arrangements by ANN.

\begin{tabular}{|c|c|c|c|c|c|c|c|c|c|c|}
\hline \multirow{3}{*}{ Independent variables } & \multicolumn{10}{|c|}{ Statistics indices } \\
\hline & \multicolumn{3}{|c|}{ Overall } & \multicolumn{3}{|l|}{ Train } & \multicolumn{3}{|l|}{ Test } & \multirow{2}{*}{$\begin{array}{l}\text { The best } \\
\text { structure }\end{array}$} \\
\hline & $\mathrm{R}^{2}$ & RMSE & RRMSE & $\mathrm{R}^{2}$ & RMSE & RRMSE & $\mathrm{R}^{2}$ & RMSE & RRMSE & \\
\hline Wheat grain yield & 0.713 & 561.134 & 0.106 & 0.722 & 540.392 & 0.102 & 0.682 & 659.413 & 0.125 & $10-7-7-1$ \\
\hline Wheat straw yield & 0.665 & 439.658 & 0.138 & 0.669 & 435.573 & 0.137 & 0.684 & 460.510 & 0.145 & $10-10-5-1$ \\
\hline Output energy (grain) & 0.764 & 7025.313 & 0.090 & 0.755 & 7168.764 & 0.092 & 0.798 & 6218.139 & 0.080 & $10-9-6-1$ \\
\hline Output energy (straw) & 0.278 & 8754.982 & 0.221 & 0.236 & 9275.302 & 0.234 & 0.602 & 5234.188 & 0.132 & $10-9-6-1$ \\
\hline
\end{tabular}




\begin{tabular}{lllllllllll} 
Total value production & 0.539 & 115.851 & 0.136 & 0.526 & 120.383 & 0.141 & 0.552 & 88.324 & 0.103 & $10-9-10-1$ \\
Net return & 0.954 & 669.146 & 0.048 & 0.956 & 662.014 & 0.048 & 0.933 & 705.407 & 0.051 & $10-9-5-1$ \\
GWP & 0.313 & 107.422 & 0.167 & 0.312 & 111.315 & 0.173 & 0.332 & 84.076 & 0.131 & $10-5-10-1$ \\
\hline
\end{tabular}

372 3.5. Evaluation of ANFIS

373 In this study, Matlab software was used for ANFIS analysis and the best integration of

374 variables in the ANFIS model with the best accuracy was identified. The statistical

375 components of the 3-level ANFIS structure in forecasting yield, economical profit and GWP

376 of wheat cultivation are listed in Table 7. According to results, accepting Gbell MFs and

377 linear MF for input and output layers, respectively; ANFIS offers the best performance. In

378 other words, this hybrid learning method can simulate the communication input and output,

379 the optimized MF contribution specify, and provide great precision.

380 The 3-level ANFIS model (ANFIS 8) shown in results study, the highest $\mathrm{R}^{2}$ is found for net

381 return (0.962). In this model, the RRMSE is computed to be 0.002. The results in the 3-level

382 ANFIS model also showed that, $\mathrm{R}^{2}$ for wheat grain yield was found to be 0.751 for the

383 ANFIS (8) model and RRMSE was calculation to be 0.008. Results of the current study

384 agreement by Kaab et al. (Kaab et al. 2019a) which applied ANFIS to forecast output energy

385 and environmental effects of sugarcane cultivation. Naderloo et al. (2012) applied ANFIS

386 model to predict the wheat grain yield in Iran. They clustered the input vector for ANFIS into

387 two groups and trained two networks. Electricity, diesel fuel and chemical fertilizer energies

388 were inputs for ANFIS 1, and machinery, labor, chemicals, water and seed energies

389 considered for ANFIS 2. They found the RMSE values to be 0.013 and 0.018 for ANFIS1

390 and ANFIS 2, respectively. Also the R2 values were found to be 0.996 and 0.992 for ANFIS 1

391 and ANFIS 2, respectively. Finally, they used these predicted values as the inputs of the third

392 ANFIS and found that the RMSE and $\mathrm{R}^{2}$ were 0.013 and 0.996 , respectively. 
Table 7

The specifications of the best structure of first ANFIS model for forecasting in wheat cultivation using 3-level ANFIS

\begin{tabular}{|c|c|c|c|c|c|c|c|c|c|}
\hline \multirow{2}{*}{ Independent variables } & \multirow{2}{*}{$\begin{array}{c}\text { Learning } \\
\text { model }\end{array}$} & \multicolumn{2}{|c|}{ Type of MF } & \multicolumn{2}{|c|}{ Number of MF } & \multirow{2}{*}{$\begin{array}{l}\text { ANFIS } \\
\text { method }\end{array}$} & \multirow{2}{*}{$\mathrm{R}^{2}$} & \multirow{2}{*}{ RMSE } & \multirow{2}{*}{ RRMSE } \\
\hline & & Input & Output & Input & Epoch & & & & \\
\hline \multirow{8}{*}{ Wheat grain yield } & \multirow{8}{*}{ Hybrid } & \multirow{8}{*}{ Gbell } & \multirow{8}{*}{ Linear } & \multirow{8}{*}{5,6} & \multirow{8}{*}{32} & 1 & 0.079 & 875161.899 & 0.031 \\
\hline & & & & & & 2 & 0.379 & 693005.099 & 0.024 \\
\hline & & & & & & 3 & 0.596 & 391588.151 & 0.014 \\
\hline & & & & & & 4 & 0.179 & 777625.403 & 0.027 \\
\hline & & & & & & 5 & 0.431 & 552506.823 & 0.019 \\
\hline & & & & & & 6 & 0.687 & 296973.736 & 0.010 \\
\hline & & & & & & 7 & 0.501 & 477831.396 & 0.017 \\
\hline & & & & & & 8 & 0.751 & 235118.837 & 0.008 \\
\hline \multirow{8}{*}{ Wheat straw yield } & & & & & & 1 & 0.046 & 536890.809 & 0.053 \\
\hline & & & & & & 2 & 0.194 & 452969.148 & 0.045 \\
\hline & & & & & & 3 & 0.353 & 362382.016 & 0.036 \\
\hline & Wryhrid & Choll $>$ (1) & I inoon $x$ & 56 & 22 & 4 & 0.131 & 490717.391 & 0.049 \\
\hline & Hybrid & Gbell & Linear & J,0 & 32 & 5 & 0.285 & 404903.776 & 0.040 \\
\hline & & & & & & 6 & 0.430 & 318452.654 & 0.032 \\
\hline & & & & & & 7 & 0.316 & 387070.218 & 0.038 \\
\hline & & & & & & 8 & 0.520 & 268382.638 & 0.027 \\
\hline & & & & & & 1 & 0.065 & $2 \mathrm{E}+08$ & 0.032 \\
\hline & & & & & & 2 & 0.494 & $1 \mathrm{E}+08$ & 0.017 \\
\hline & & & & & & 3 & 0.590 & $8 \mathrm{E}+07$ & 0.014 \\
\hline & & & & & 32 & 4 & 0.178 & $2 \mathrm{E}+08$ & 0.028 \\
\hline Output energy (grain) & Hybrid & Gbell & Linear & 5,6 & 32 & 5 & 0.397 & $1 \mathrm{E}+08$ & 0.020 \\
\hline & & & & & & 6 & 0.633 & $9 \mathrm{E}+07$ & 0.015 \\
\hline & & & & & & 7 & 0.316 & $2 \mathrm{E}+08$ & 0.033 \\
\hline & & & & & & 8 & 0.720 & $6 \mathrm{E}+07$ & 0.010 \\
\hline & & & & & & 1 & 0.051 & $8 \mathrm{E}+07$ & 0.053 \\
\hline & & & & & & 2 & 0.135 & $1 \mathrm{E}+08$ & 0.069 \\
\hline & & & & & & 3 & 0.323 & $6 \mathrm{E}+07$ & 0.038 \\
\hline & & & & & & 4 & 0.089 & $8 \mathrm{E}+07$ & 0.051 \\
\hline Output energy (straw) & Hybrid & Gbell & Linear & 5,6 & 32 & 5 & 0.277 & $6 \mathrm{E}+07$ & 0.040 \\
\hline & & & & & & 6 & 0.426 & $5 \mathrm{E}+07$ & 0.032 \\
\hline & & & & & & 7 & 0.317 & $6 \mathrm{E}+07$ & 0.038 \\
\hline & & & & & & 8 & 0.520 & $4 \mathrm{E}+07$ & 0.027 \\
\hline & & & & & & 1 & 0.054 & 23848.661 & 0.033 \\
\hline & & & & & & 2 & 0.437 & 14206.549 & 0.019 \\
\hline & & & & & & 3 & 0.577 & 10692.658 & 0.015 \\
\hline Total yalue production & & & & & & 4 & 0.191 & 20429.046 & 0.028 \\
\hline Total value production & Hybrid & Gbell & Linear & 5,6 & 32 & 5 & 0.407 & 14951.523 & 0.020 \\
\hline & & & & & & 6 & 0.681 & 8109.329 & 0.011 \\
\hline & & & & & & 7 & 0.446 & 13918.281 & 0.019 \\
\hline & & & & & & 8 & 0.716 & 7234.989 & 0.010 \\
\hline & & & & & & 1 & 0.187 & 7933570.020 & 0.041 \\
\hline & & & & & & 2 & 0.208 & 8276753.136 & 0.043 \\
\hline & & & & & & 3 & 0.862 & 1349238.577 & 0.007 \\
\hline & & Chell & Iineor & 56 & 32 & 4 & 0.369 & 6189360.849 & 0.032 \\
\hline Net return & Hybrid & Gbell & Linear & 5,6 & 32 & 5 & 0.453 & 5465424.277 & 0.029 \\
\hline & & & & & & 6 & 0.871 & 1259206.718 & 0.007 \\
\hline & & & & & & 7 & 0.524 & 4734245.043 & 0.025 \\
\hline & & & & & & 8 & 0.962 & 369993.218 & 0.002 \\
\hline & & & & & & 1 & 0.077 & 15590.825 & 0.038 \\
\hline & & & & & & 2 & 0.024 & 16397.393 & 0.040 \\
\hline & & & & & & 3 & 0.079 & 15486.506 & 0.037 \\
\hline & & & & & & 4 & 0.060 & 15817.617 & 0.038 \\
\hline GWP & Hybrid & Gbell & Linear & 5,6 & 32 & 5 & 0.144 & 14309.311 & 0.035 \\
\hline & & & & & & 6 & 0.208 & 13500.011 & 0.033 \\
\hline & & & & & & 7 & 0.176 & 13883.412 & 0.033 \\
\hline & & & & & & 8 & 0.543 & 7696.054 & 0.019 \\
\hline
\end{tabular}


396 In the final part of the research, the results of different models including linear regression,

397 ANFIS and ANN models were evaluated using coefficients of determination. Fig. 8 shows $\mathrm{R}^{2}$ 398 in different models. According to Fig. 8, the $\mathrm{R}^{2}$ index obtained by ANFIS model for 399 predicting dependent variables; including wheat grain yield, output energy (straw), total value 400 production, and GWP are higher than $\mathrm{R}^{2}$ of other models. In other words, ANFIS model 401 outperforms other models. However, $\mathrm{R}^{2}$ obtained by ANN model for predicting wheat straw 402 yield and output energy (grain) are higher than $\mathrm{R}^{2}$ of other models. Regarding the net return 403 index, there was no significant difference between the accuracy of the three models. 404 According to Fig. 8, both models of ANN and ANFIS can predict yield, economic profit, and 405 global warming of wheat production with fair accuracy. The observation agrees well with the 406 findings reported by Khashei-Siuki et al. (2011) to predict wheat yield and for tomato 407 production in greenhouse (Khoshnevisan et al. 2015). In a study carried out by Kaab et al. 408 (Kaab et al. 2019a), ANFIS and ANN models have been used to forecast energy output and 409 environmental issue of sugarcane farms. The results showed that in the plant farms ANN 410 model is better than ANFIS in all dimensions, but in case of ratoon farms, ANFIS models 411 achieve better accuracy than ANN prediction. 


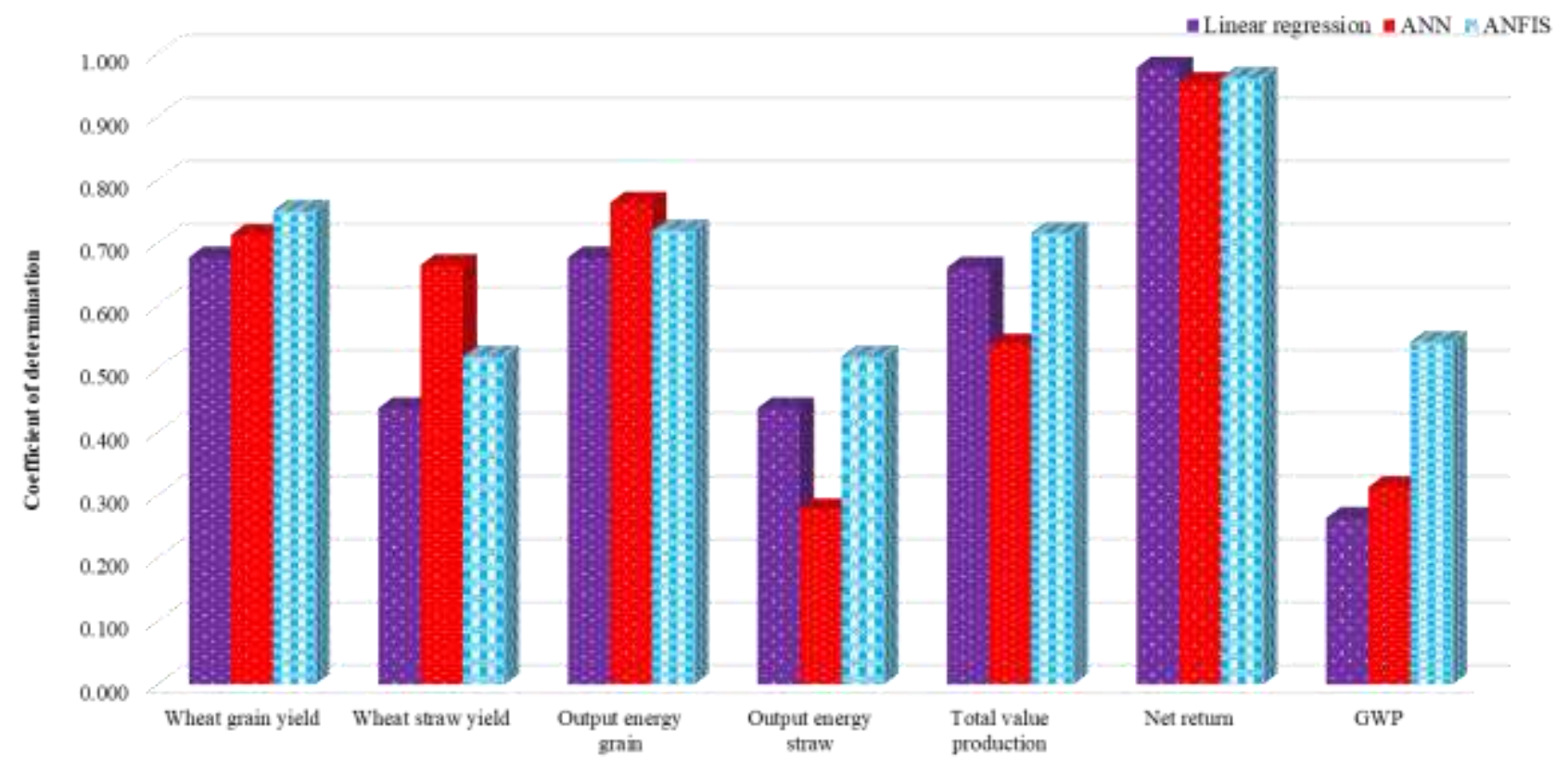

Fig. 8. Comparison between $\mathrm{R}^{2}$ in different models.

\section{4. Conclusions}

413 The purpose of this research was to applied linear regression, ANNs, and ANFIS models to

414 predict yield, economic profit, and global warming of wheat production. Moreover, LCA was

415 used to evaluate the environmental issue of wheat cultivation in the central area of Hamedan

416 state. Based on the results obtained from current study, the mean wheat grain and straw yield

417 were about 5287 and $3175 \mathrm{~kg} \mathrm{ha}^{-1}$, respectively, and the mean output and inputs energy are

418 117407.13 $\mathrm{MJ} \mathrm{ha}^{-1}$ and $43054.63 \mathrm{MJ} \mathrm{ha}^{-1}$, respectively. Electricity was highest in

419 consumption of energy in wheat farms. The results of normalization in LCA showed that ME

420 has the highest environmental pollution in wheat farms. The linear regression results

421 demonstrated that the $\mathrm{R}^{2}$ value for net return predicting was 0.978 , indicating that this model

422 can explain about 0.98 of the variability in the net return. The results of ANN model showed

423 the structures with two hidden layers were the best topologies, and ANFIS results in the third-

424 level demonstrated, the highest $\mathrm{R}^{2}$ is found for net return is 0.962 in ANFIS eight. In this

425 study according to linear regression, ANN and ANFIS models are expanded to predicted 
426 yield, economic profit, and global warming for wheat production. Modeling results with 427 ANN and ANFIS better than by linear regression in wheat cultivation. Due to the uncertainty, 428 ANFIS models are outperform ANN and linear regression models. Generally, in modeling 429 and forecasting, ANFIS models are better than ANN and linear regression models, 430 considering different social and technical factors in wheat farms to help decision makers to 431 solve the problem of sustainability from different aspects.

\section{Declarations}

434 Ethics approval and consent to participate: Not applicable.

435 Consent for publication: Not applicable.

436 Availability of data and materials: Not applicable.

437 Competing interests: The authors declare that they have no competing interests.

438 Funding: Not applicable.

439 Authors Contributions: Hassan Ghasemi-Mobtaker: Data curation, Validation, Writing-

440 Original draft, Reviewing and Editing, Supervision, Ali Kaab: Investigation, Writing-

441 Reviewing and Editing, Methodology, Shahin Rafiee: Formal analysis, Software.

442

443 References

444 Abdi R, Hematian A, Ghasemi H, Shahamat EZ (2012) Sensitivity analysis of energy inputs for maize production system in Kermanshah province of Iran. Int J Plant, Anim Environ Sci 2:84-90

Ahmed AAM, Shah SMA (2017) Application of adaptive neuro-fuzzy inference system (ANFIS) to estimate the biochemical oxygen demand (BOD) of Surma River. J King Saud Univ - Eng Sci 29:237-243. 
450 Akib S, Mohammadhassani M, Jahangirzadeh A (2014) Application of ANFIS and LR in prediction of scour depth in bridges. Comput Fluids 91:77-86.

452 Alhajj Ali S, Tedone L, De Mastro G (2013) A comparison of the energy consumption of rainfed durum wheat under different management scenarios in southern Italy. Energy 61:308-318.

Ali M, Deo RC (2020) Modeling wheat yield with data-intelligent algorithms. In: Handbook of Probabilistic Models. Elsevier, pp 37-87

Amirkhani S, Nasirivatan SH, Kasaeian AB, Hajinezhad A (2015) ANN and ANFIS models to predict the performance of solar chimney power plants. Renew Energy 83:597-607

Amoozad-Khalili M, Rostamian R, Esmaeilpour-Troujeni M, Kosari-Moghaddam A (2020) Economic modeling of mechanized and semi-mechanized rainfed wheat production systems using multiple linear regression model. Inf Process Agric 7:30-40.

Antanasijević D, Pocajt V, Ristić M, Perić-Grujić A (2015) Modeling of energy consumption 463 and related GHG (greenhouse gas) intensity and emissions in Europe using general regression neural networks. Energy 84:816-824.

Canakci M, Topakci M, Akinci I, Ozmerzi A (2005) Energy use pattern of some field crops and vegetable production: Case study for Antalya Region, Turkey. Energy Convers Manag 46:655-666.

Cavalliere C, Dell'Osso GR, Pierucci A, Iannone F (2018) Life cycle assessment data structure for building information modelling. J Clean Prod 199:193-204.

Chang Y-C, Lee W-J, Wang L-C, et al (2014) Effects of waste cooking oil-based biodiesel on the toxic organic pollutant emissions from a diesel engine. Appl Energy 113:631-638

472 Chen P, Jing Q (2017) A comparison of two adaptive multivariate analysis methods (PLSR 

and ANN) for winter wheat yield forecasting using Landsat-8 OLI images. Adv Sp Res 59:987-995

475

476

478

480

481

482

483

484

485

486

487

488

489

490

491

492

493

494

495

Chen X, Thorp KR, Ouyang Z, et al (2019) Energy consumption due to groundwater pumping for irrigation in the North China Plain. Sci Total Environ 669:1033-1042.

Curran MA (2017) Overview of Goal and Scope Definition in Life Cycle Assessment. Springer, Dordrecht, pp 1-62

Elhami B, Khanali M, Akram A (2017) Combined application of Artificial Neural Networks and life cycle assessment in lentil farming in Iran. Inf Process Agric 4:18-32.

Estelles-Lopez L, Ropodi A, Pavlidis D, et al (2017) An automated ranking platform for machine learning regression models for meat spoilage prediction using multi-spectral imaging and metabolic profiling. Food Res Int 99:206-215.

Fathollahi H, Mousavi-Avval SH, Akram A, Rafiee S (2018) Comparative energy, economic and environmental analyses of forage production systems for dairy farming. J Clean Prod 182:852-862

Ferreira AF, Ribau JP, Silva CM (2011) Energy consumption and CO2 emissions of potato peel and sugarcane biohydrogen production pathways, applied to Portuguese road transportation. Int J Hydrogen Energy 36:13547-13558.

Ghasemi-Mobtaker H, Akram A, Keyhani A (2012) Energy use and sensitivity analysis of energy inputs for alfalfa production in Iran. Energy Sustain Dev 16:84-89

Ghasemi-Mobtaker H, Kaab A, Rafiee S (2020a) Application of life cycle analysis to assess environmental sustainability of wheat cultivation in the west of Iran. Energy 193:116768.

Ghasemi-Mobtaker H, Keyhani A, Mohammadi A, et al (2010) Sensitivity analysis of energy 

inputs for barley production in Hamedan Province of Iran. Agric Ecosyst Environ 137:367-372.

Ghasemi-Mobtaker H, Mostashari-Rad F, Saber Z, et al (2020b) Application of photovoltaic system to modify energy use, environmental damages and cumulative exergy demand of two irrigation systems-A case study: Barley production of Iran. Renew Energy 160:1316-1334.

502

Ghasemi Mobtaker H, Akram A, Keyhani A (2010) Economic modeling and sensitivity 503 analysis of the costs of inputs for alfalfa production In Iran: A case study from Hamedan province. Ozean J Appl Sci 3:313-319

Grados D, Schrevens E (2019) Multidimensional analysis of environmental impacts from potato agricultural production in the Peruvian Central Andes. Sci Total Environ

Hasler K, Bröring S, Omta SWF, Olfs H-W (2015) Life cycle assessment (LCA) of different fertilizer product types. Eur J Agron 69:41-51

Hatirli SA, Ozkan B, Fert C (2006) Energy inputs and crop yield relationship in greenhouse tomato production. Renew Energy 31:427-438

Justesen KK, Andreasen SJ, Sahlin SL (2015) Modeling of a HTPEM fuel cell using Adaptive Neuro-Fuzzy Inference Systems. Int J Hydrogen Energy 40:16814-16819.

Kaab A, Sharifi M, Mobli H, et al (2019a) Combined life cycle assessment and artificial intelligence for prediction of output energy and environmental impacts of sugarcane production. Sci Total Environ 664:1005-1019

Kaab A, Sharifi M, Mobli H, et al (2019b) Use of optimization techniques for energy use efficiency and environmental life cycle assessment modification in sugarcane production. Energy 181:1298-1320. 
520 Kalogirou S, Bojic M (2000) Artificial neural networks for the prediction of the energy consumption of a passive solar building. Energy 25:479-491.

Khakbazan M, Mohr RM, Derksen DA, et al (2009) Effects of alternative management practices on the economics, energy and GHG emissions of a wheat-pea cropping system in the Canadian prairies. Soil Tillage Res 104:30-38.

Khanali M, Mobli H, Hosseinzadeh-Bandbafha H (2017) Modeling of yield and environmental impact categories in tea processing units based on artificial neural networks. Environ Sci Pollut Res 24:26324-26340

Khashei-Siuki A, Kouchakzadeh M, Ghahraman B (2011) Predicting Dryland Wheat Yield from Meteorological Data Using Expert System, Khorasan Province, Iran. Journal of

Khoshnevisan B, Rafiee S, Iqbal J, et al (2015) A Comparative Study Between Artificial Neural Networks and Adaptive Neuro-Fuzzy Inference Systems for Modeling Energy Consumption in Greenhouse Tomato Production: A Case Study in Isfahan Province. Journal of Agricultural Science and Technology

Khoshnevisan B, Rafiee S, Mousazadeh H (2013) Environmental impact assessment of open field and greenhouse strawberry production. Eur J Agron 50:29-37.

Khoshnevisan B, Rafiee S, Omid M, et al (2014) Environmental impact assessment of tomato and cucumber cultivation in greenhouses using life cycle assessment and adaptive neuro-fuzzy inference system. J Clean Prod 73:183-192.

Khoshroo A, Emrouznejad A, Ghaffarizadeh A, et al (2018) Sensitivity analysis of energy inputs in crop production using artificial neural networks. J Clean Prod 197:992-998. wheat model. Eur J Agron 109:125901. 
544 Mälkki H, Alanne K (2017) An overview of life cycle assessment (LCA) and research-based 545 teaching in renewable and sustainable energy education. Renew Sustain Energy Rev 69:218-231

Meng X, Chen L, Cai J, et al (2015) A land use regression model for estimating the NO2 concentration in shanghai, China. Environ Res 137:308-315.

Mensour ON, El Ghazzani B, Hlimi B, Ihlal A (2017) Modeling of solar energy potential in Souss-Massa area-Morocco, using intelligence Artificial Neural Networks (ANNs). In: Energy Procedia. Elsevier Ltd, pp 778-784

Ministry of Jihad-e-Agriculture of Iran (2019) Annual Agricultural Statistics. www.maj.ir (in Persian).

Mohammadi A, Rafiee S, Jafari A, et al (2015) Joint Life Cycle Assessment and Data Envelopment Analysis for the benchmarking of environmental impacts in rice paddy production. J Clean Prod 106:521-532

Mohammadi A, Rafiee S, Jafari A, et al (2014) Energy use efficiency and greenhouse gas emissions of farming systems in north Iran. Renew Sustain Energy Rev 30:724-733

Mohammadi A, Rafiee S, Mohtasebi SS, et al (2010a) Developing an artificial neural network model for predicting kiwifruit production in Mazandaran province of Iran. In: Agriculture Engineering Conference. pp 16-20

Mohammadi A, Rafiee S, Mohtasebi SS, Rafiee H (2010b) Energy inputs-yield relationship and cost analysis of kiwifruit production in Iran. Renew energy 35:1071-1075 45. 
Mostashari-Rad F, Ghasemi-Mobtaker H, Taki M, et al (2021) Exergoenvironmental damages assessment of horticultural crops using ReCiPe2016 and cumulative exergy demand frameworks. J Clean Prod 278:123788.

Mousavi-Avval SH, Rafiee S, Sharifi M, et al (2017) Combined application of Life Cycle Assessment and Adaptive Neuro-Fuzzy Inference System for modeling energy and

Nabavi-Pelesaraei A, Abdi R, Rafiee S (2014) Applying artificial neural networks and multiobjective genetic algorithm to modeling and optimization of energy inputs and greenhouse gas emissions for peanut production. Int J Biosci 4:170-183.

Nabavi-Pelesaraei A, Rafiee S, Mohtasebi SS, et al (2018) Integration of artificial intelligence methods and life cycle assessment to predict energy output and environmental impacts of paddy production. Sci Total Environ 631-632:1279-1294.

Nabavi-Pelesaraei A, Rafiee S, Mohtasebi SS, et al (2019) Comprehensive model of energy, environmental impacts and economic in rice milling factories by coupling adaptive neuro-fuzzy inference system and life cycle assessment. J Clean Prod 217:742-756.

Naderloo L, Alimardani R, Omid M, et al (2012) Application of ANFIS to predict crop yield based on different energy inputs. Meas J Int Meas Confed 45:1406-1413.

Ozkan B, Akcaoz H, Fert C (2004) Energy input-output analysis in Turkish agriculture. Renew Energy 29:39-51

Ozkan B, Ceylan RF, Kizilay H (2011) Energy inputs and crop yield relationships in greenhouse winter crop tomato production. Renew Energy 36:3217-3221.

Petković D (2015) Adaptive neuro-fuzzy approach for estimation of wind speed distribution. Int J Electr Power Energy Syst 73:389-392. 
590 Raheli H, Rezaei RM, Jadidi MR, Mobtaker HG (2017) A two-stage DEA model to evaluate sustainability and energy efficiency of tomato production. Inf Process Agric 4:342-350.

Ranković V, Grujović N, Divac D, et al (2012) Modelling of dam behaviour based on neurofuzzy identification. Eng Struct 35:107-113.

Recanati F, Arrigoni A, Scaccabarozzi G, et al (2018) LCA Towards Sustainable Agriculture: The Case Study of Cupuaçu Jam from Agroforestry. Procedia CIRP 69:557-561.

Romero-Gámez M, Audsley E, Suárez-Rey EM (2014) Life cycle assessment of cultivating lettuce and escarole in Spain. J Clean Prod 73:193-203.

Salehi M, Ebrahimi R, Maleki A, Ghasemi Mobtaker H (2014) An assessment of energy modeling and input costs for greenhouse button mushroom production in Iran. J Clean Prod 64:377-383.

601

602

Singh H, Mishra D, Nahar NM (2002) Energy use pattern in production agriculture of a typical village in arid zone, India—part I. Energy Convers Manag 43:2275-2286.

Singh H, Singh AK, Kushwaha HL, Singh A (2007) Energy consumption pattern of wheat 604 production in India. Energy 32:1848-1854.

605

Singh R, Kainthola A, Singh TN (2012) Estimation of elastic constant of rocks using an 606 ANFIS approach. Appl Soft Comput 12:40-45

607

608

Soltanali H, Nikkhah A, Rohani A (2017) Energy audit of Iranian kiwifruit production using

.

Soltani A, Rajabi MH, Zeinali E, Soltani E (2013) Energy inputs and greenhouse gases

610 emissions in wheat production in Gorgan, Iran. Energy 50:54-61.

611 Tabatabaeefar A, Emamzadeh H, Ghasemi Varnamkhasti M, et al (2009) Comparison of 612 energy of tillage systems in wheat production. Energy 34:41-45. 
613 Taheri-Rad A, Khojastehpour M, Rohani A, et al (2017) Energy flow modeling and 614 predicting the yield of Iranian paddy cultivars using artificial neural networks. Energy $615 \quad 135: 405-412$.

616 Taki M, Abdi R, Akbarpour M, Ghasemi-Mobtaker H (2013) Energy inputs - Yield 617 relationship and sensitivity analysis for tomato greenhouse production in Iran. Agric Eng $618 \quad$ Int CIGR J 15:59-67

619 Taki M, Ajabshirchi Y, Mahmoudi A (2012a) Prediction of output energy for wheat 620 production using artificial neural networks in Esfahan province of Iran. J Agric Technol $8: 1229-1242$

Taki M, Ajabshirchi Y, Ranjbar SF, et al (2016) Heat transfer and MLP neural network models to predict inside environment variables and energy lost in a semi-solar greenhouse. Energy Build 110:314-329.

Taki M, Mahmoudi A, Ghasemi-Mobtaker H, Rahbari H (2012b) Energy consumption and 626 modeling of output energy with multilayer feed-forward neural network for corn silage in Iran. Agric Eng Int CIGR J 14:93-101

Tonini D, Astrup T (2012) Life-cycle assessment of a waste refinery process for enzymatic treatment of municipal solid waste. Waste Manag 32:165-176

Zangeneh M, Omid M, Akram A (2010) A comparative study on energy use and cost analysis of potato production under different farming technologies in Hamadan province of Iran. Energy 35:2927-2933

Zangeneh M, Omid M, Akram A (2011) A comparative study between parametric and artificial neural networks approaches for economical assessment of potato production in Iran. Spanish J Agric Res 3:661-671

636 


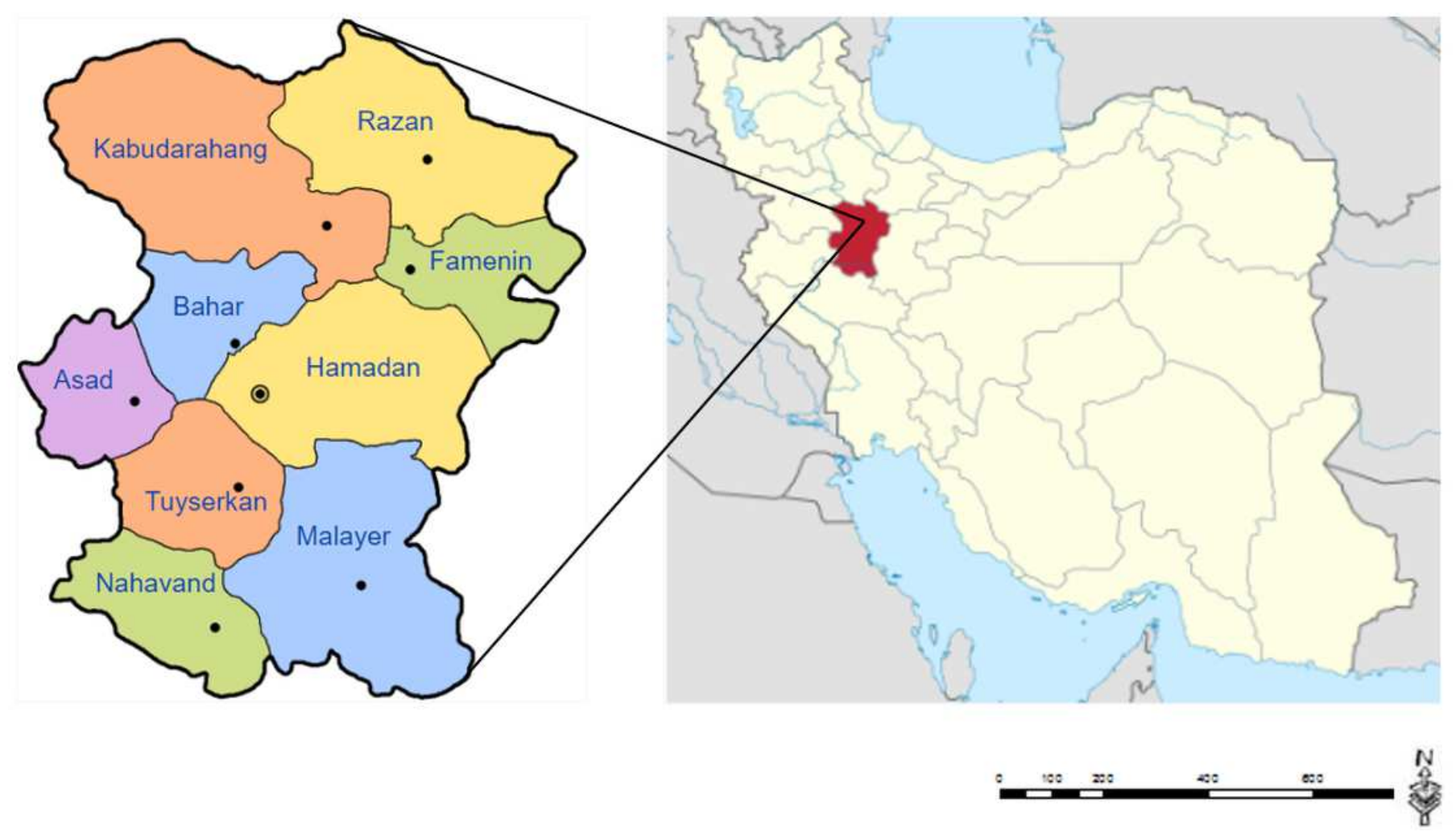

\section{Figure 1}

Geographical location of the Hamedan province Note: The designations employed and the presentation of the material on this map do not imply the expression of any opinion whatsoever on the part of Research Square concerning the legal status of any country, territory, city or area or of its authorities, or concerning the delimitation of its frontiers or boundaries. This map has been provided by the authors. 


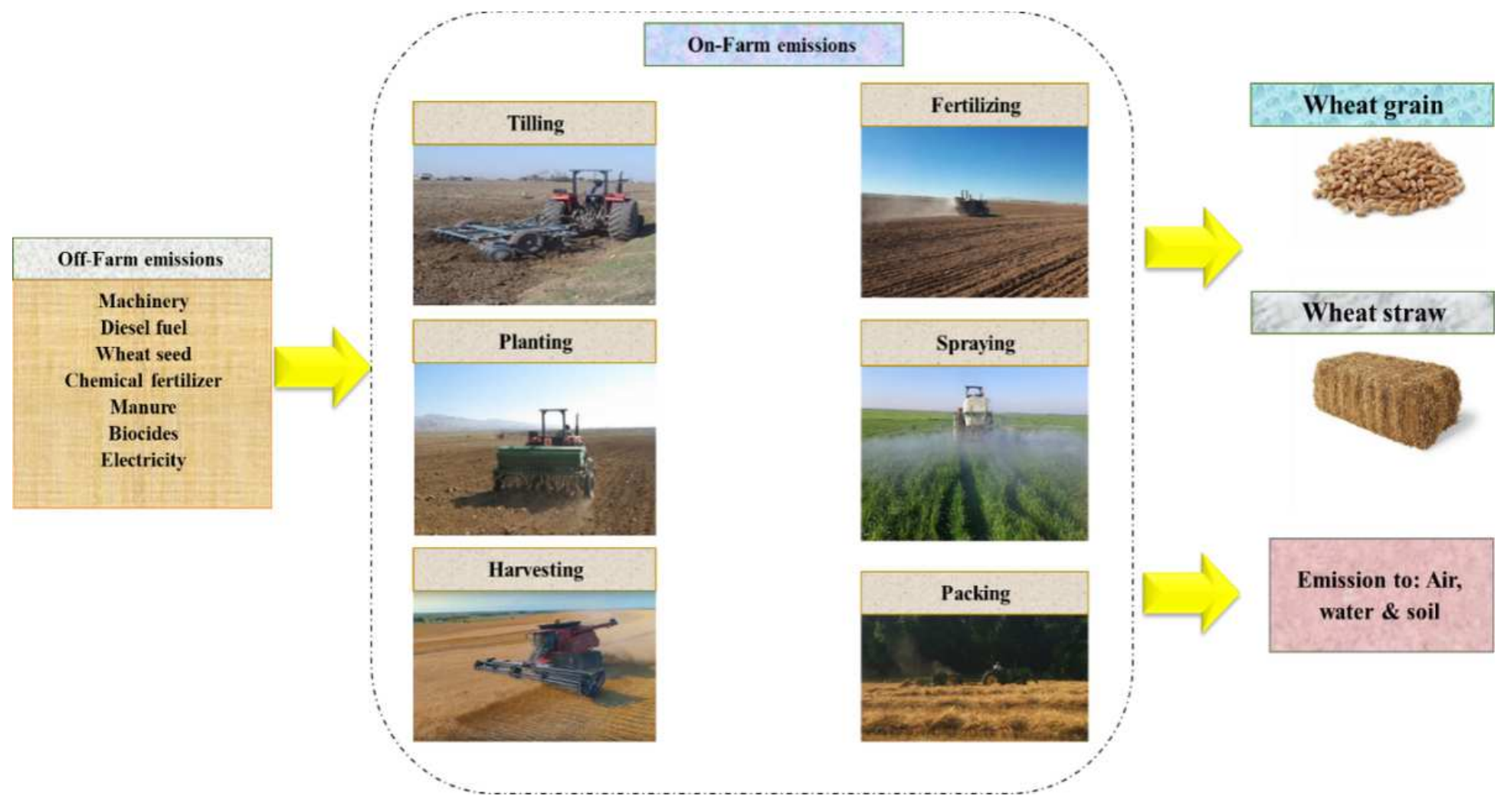

Figure 2

System boundaries of wheat production in Hamedan province of Iran.

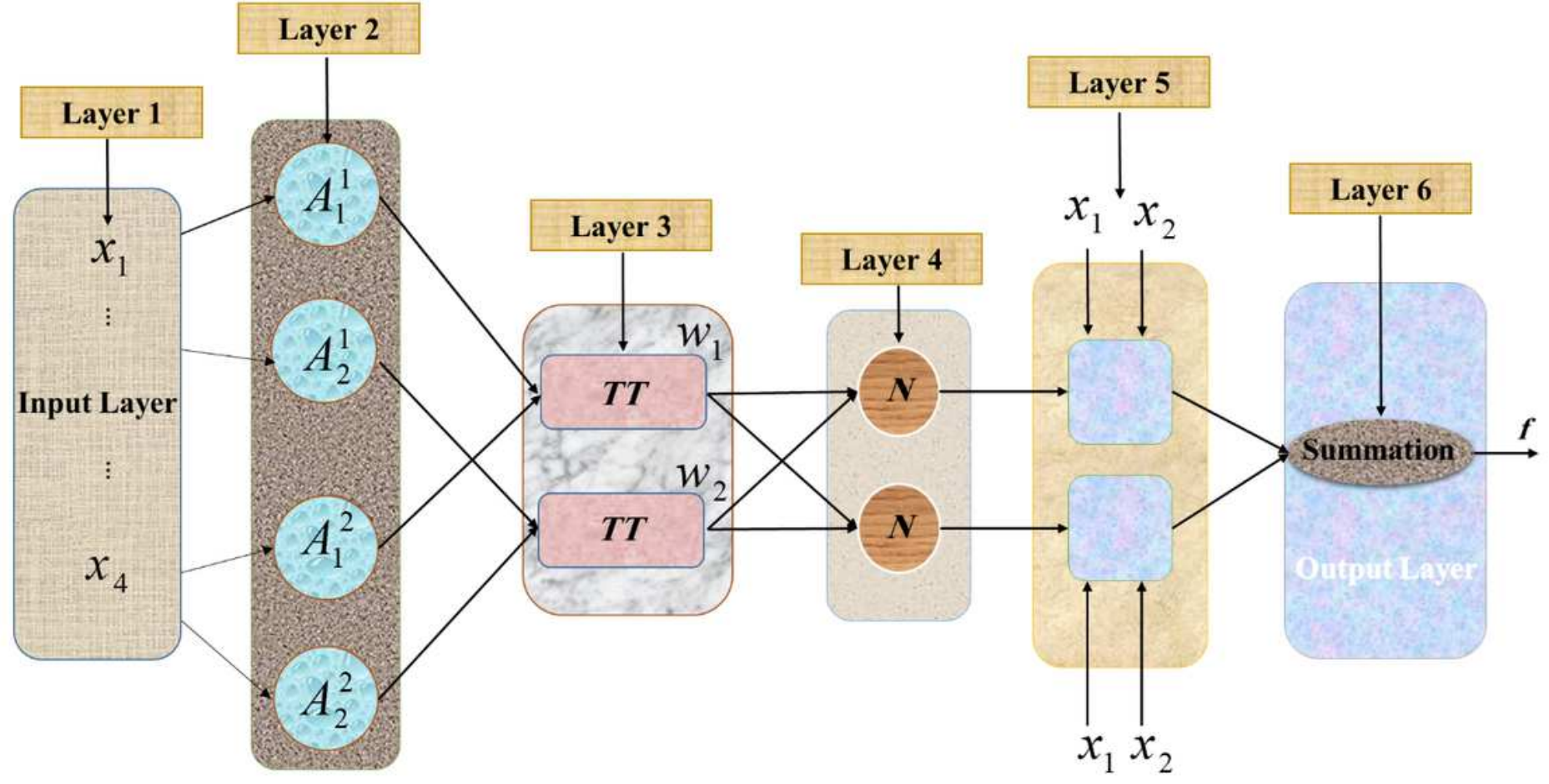

Figure 3

The ANFIS model structure. 


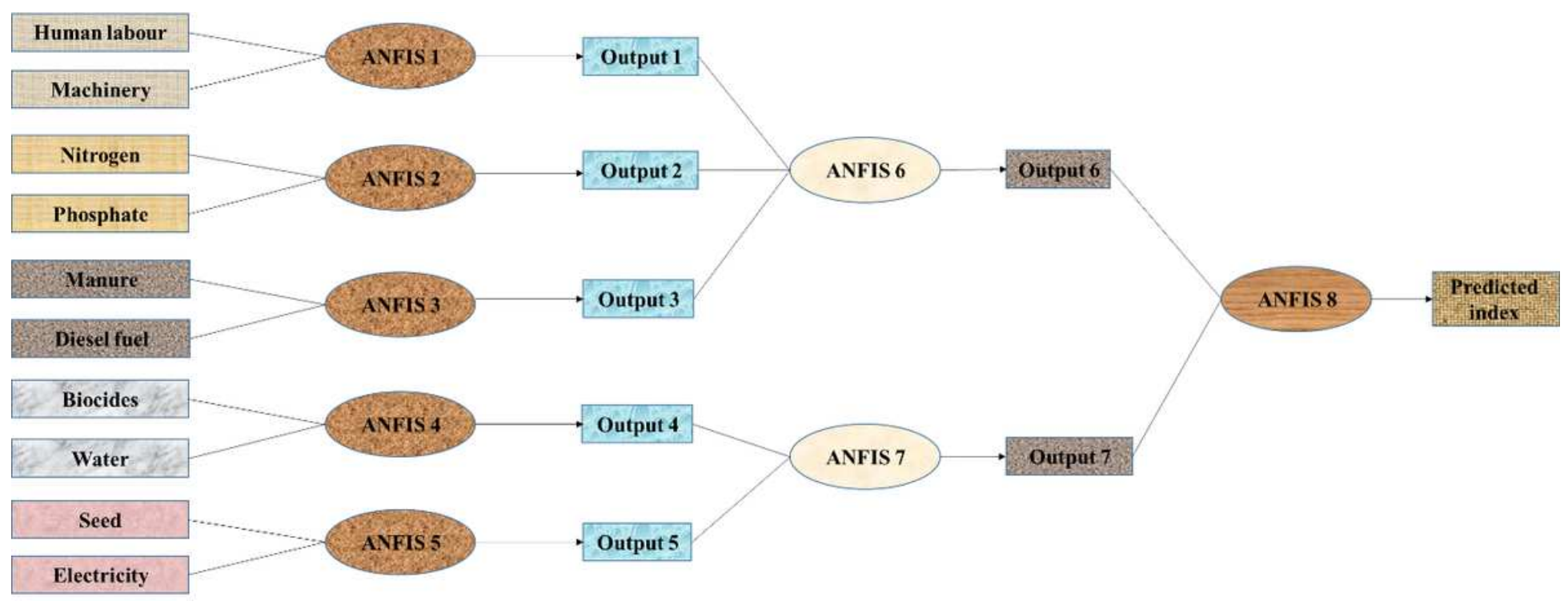

Figure 4

3-level ANFIS structure to forecast wheat yield, economical profit, and GWP of wheat cultivation.

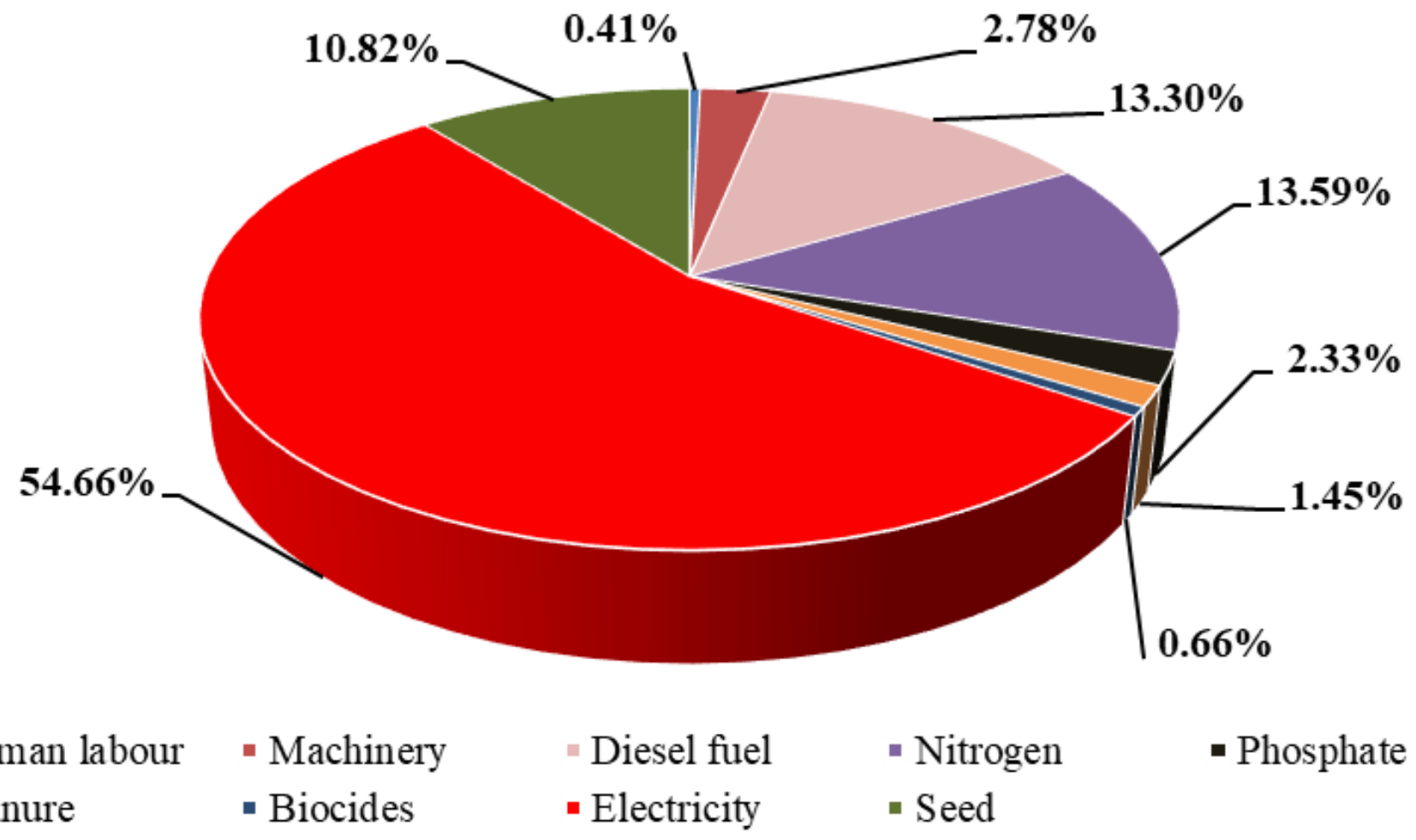

Figure 5

The energy input quota for wheat production in study region. 


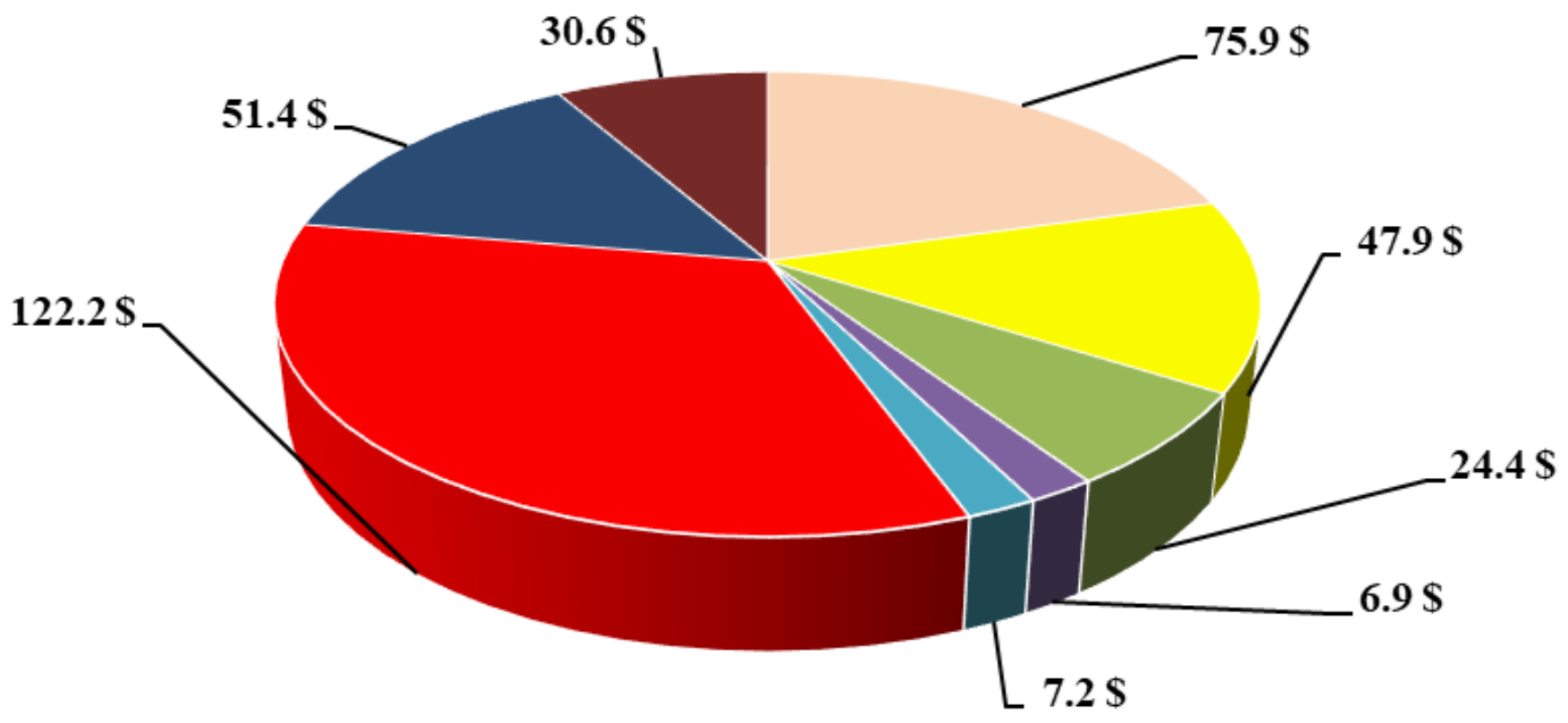
Human labour
Machinery and Diesel fuel
- Chemical fertilizers
- Manure
- Biocides
- Electricity and water
- Seed
- Rent of land

Figure 6

The percent of input costs for wheat cultivation in study region.

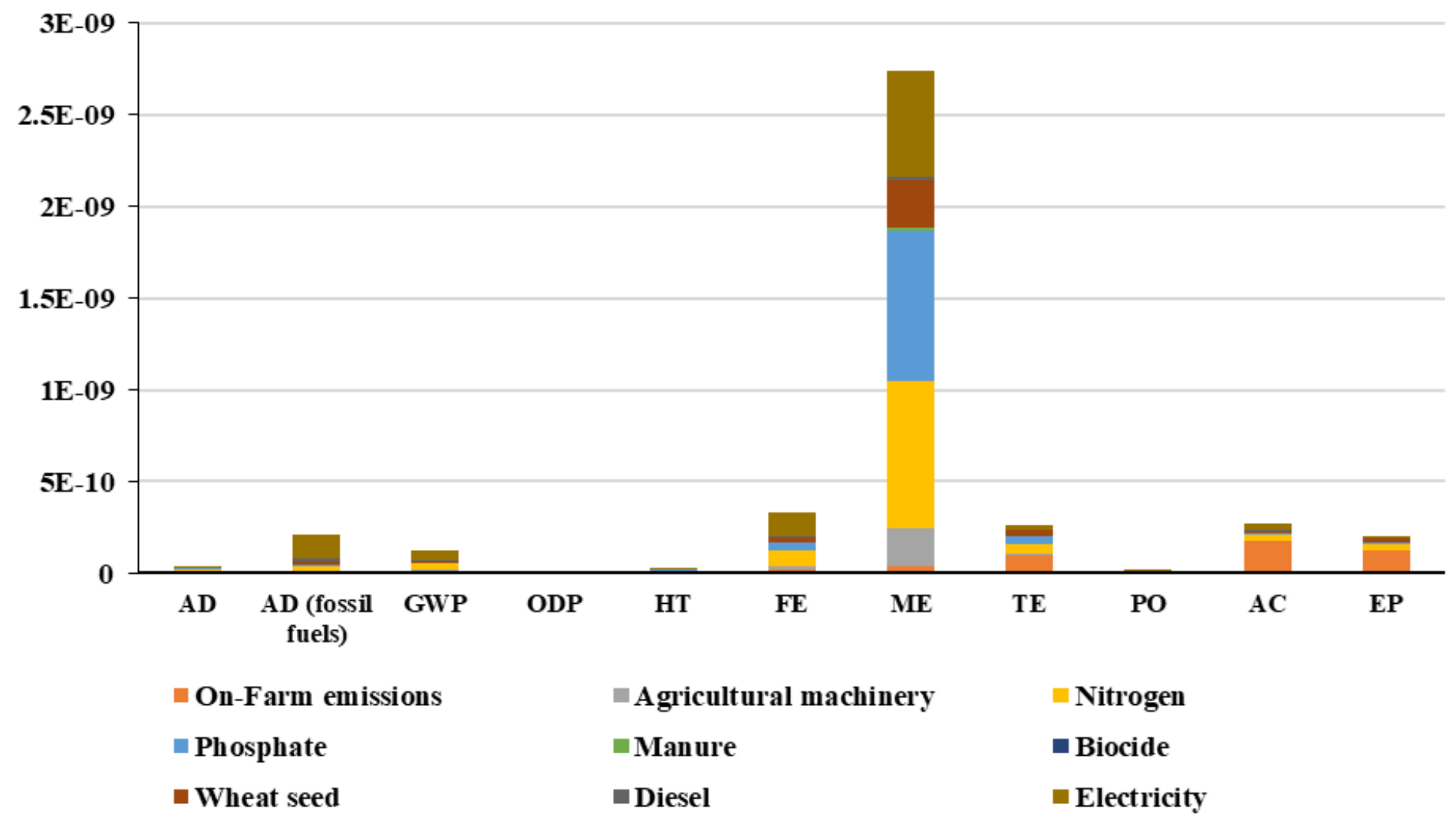


Figure 7

Normalization of different inputs in the environmental impact categories for wheat production.

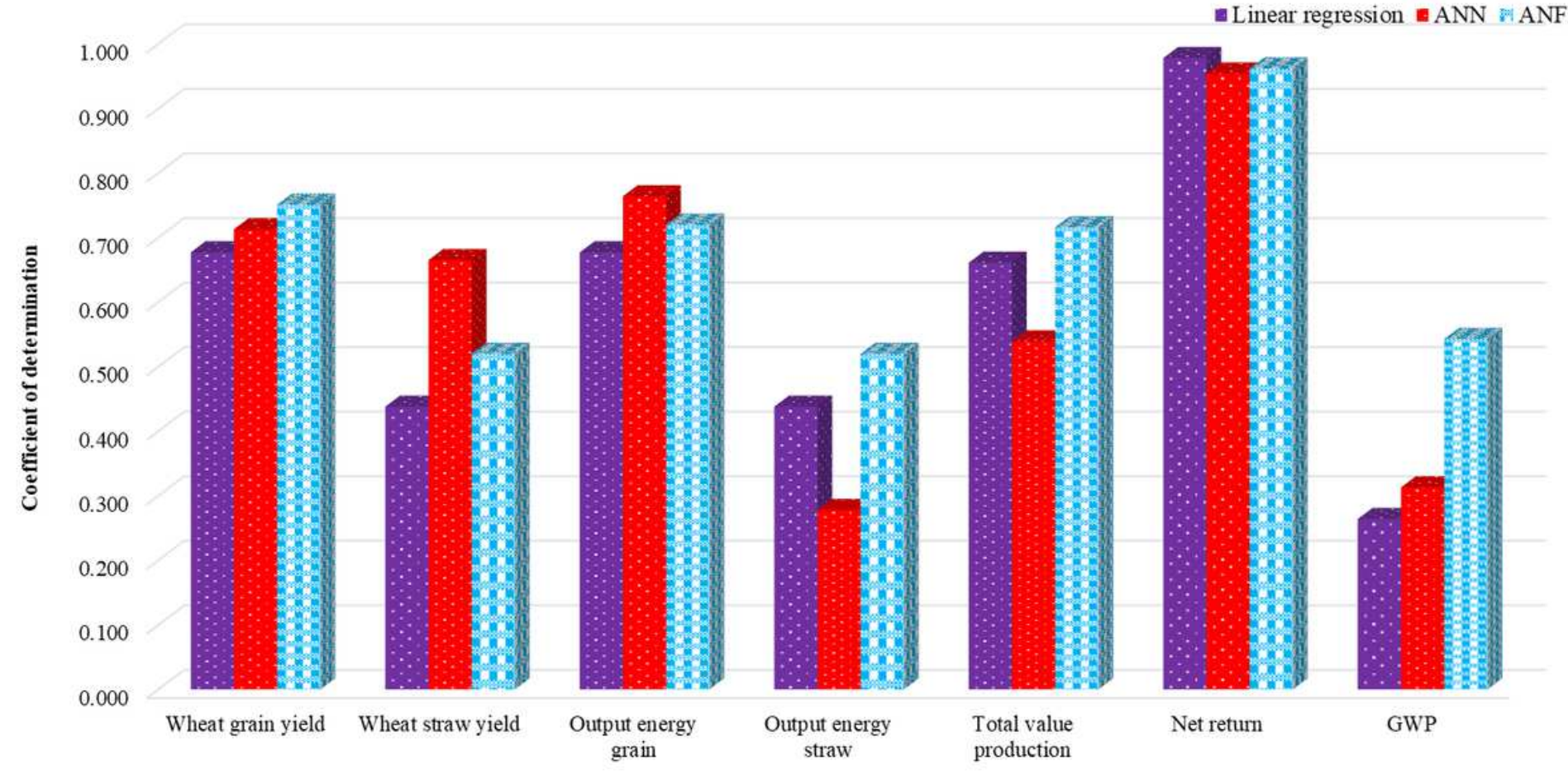

Figure 8

Comparison between R2 in different models.

\section{Supplementary Files}

This is a list of supplementary files associated with this preprint. Click to download.

- GharghicalAbstract.docx

- Highlights.docx 